\title{
Social Network Structures and the Politics of Public Goods Provision: Evidence from the Philippines ${ }^{\Uparrow}$
}

\author{
Cesi Cruz ${ }^{\dagger}$ \\ Julien Labonne ${ }^{\ddagger}$ \\ Pablo Querubin $\$$
}

\section{October 2019}

\begin{abstract}
We study the relationship between social structure and political incentives for public goods provision. We argue that when politicians-rather than communities-are responsible for the provision of public goods, social fractionalization may decrease the risk of elite capture and lead to increased public goods provision and electoral competition. We test this using large-scale data on family networks from over 20 million individuals in 15,000 villages of the Philippines. We take advantage of naming conventions to assess intermarriage links between families and use community detection algorithms to identify the relevant clans in those villages. We show that there is more public goods provision and political competition in villages with more fragmented social networks, a result that is robust to controlling for a large number of village characteristics and to alternative estimation techniques.
\end{abstract}

*A previous version of this paper circulated under the title Village Social Network Structures and Electoral Competition. We thank Klaus Desmet, Nick Eubank, James Fowler, Yana Gorokhovskaia, Saad Gulzar, Steph Haggard, Alex Hughes, Matias Iaryczower, Franziska Keller, Stuti Khemani, Alexander Kustov, Anja Prummer, Laura Schechter, Sarah ShairRosenfeld, Jake Shapiro, and Francesco Trebbi for helpful suggestions. We are also grateful to seminar and workshop participants at ASOG, Barcelona Summer Forum, Barcelona's Workshop on the Political Economy of Development and Conflict, Emory University, LSE-NYU Conference, Moscow Political Economy and Development Workshop, University of Oslo, Princeton Political Economy Workshop, Ryerson University, University of Virginia, University of British Columbia, University of California, San Diego, University of Pennsylvania, University of the Philippines School of Economics, Warwick, University of Wisconsin AAE, and World Bank ABCDE for feedback. All remaining errors are ours.

${ }^{\dagger}$ University of British Columbia: cesi.cruz@ubc.ca

‡University of Oxford: julien.labonne@bsg.ox.ac.uk

§New York University: pablo.querubin@nyu.edu 
The campaign (...) is the culmination of a contest to see who makes best use of the social structure.

Mary Hollsteiner, The Dynamics of Power

\section{Introduction}

Political institutions are built on existing social structures, with their own hierarchies, rules, and norms governing interactions and behavior. The existing literature often focuses on ethnic and religious cleavages and associates social cohesion with a host of positive outcomes such as greater public goods provision, arguing that fractionalization undermines communities' collective action and aggregation of preferences. However, in most developing countries, politicians (and not communities) are responsible for the provision of public goods which are funded with transfers (rather than local taxes). In these contexts, the implication of social fractionalization for collective action and preference aggregation may be less relevant for understanding public goods provision. Thus, it is essential to understand how social structures shape the incentives of local politicians to allocate resources across communities.

We offer a new framework for theorizing about the link between social structure - the configuration and relative position of social groups - and subsequent electoral strategies for redistribution. We argue that in weakly institutionalized and clientelistic democracies, social cohesion can also facilitate elite capture, by concentrating political influence in a handful of leaders who can help provide votes in exchange for private transfers. Consequently, if society is divided into multiple relevant social groups, the subsequent redistributive strategies adopted by politicians to attract voters may shift towards greater-rather than lower-public goods provision.

We study these questions in the context of local politics in the Philippines. The provision of public goods in the Philippines is partly the responsibility of elected municipal mayors whose budgets depend mostly on transfers from the central government. Mayors must allocate their budget across the different barangays (villages) that compose the municipality. A critical actor in Filipino social and political life are clans or extended families: political alliances at the local level often involve securing the support of clan leaders who can leverage strong norms of in-group 
cooperation and reciprocity to deliver the votes of their family members and other members of the community (Hollnsteiner, 1963: Timberman, 1991; Fegan, 2009).

We demonstrate that mayor decisions to provide public goods across the different villages that comprise their municipality vary as a function of the social structure of the village. To do this, we use a unique dataset covering 20 million individuals in more than 15,000 villages across 709 municipalities of the Philippines. The dataset includes information on family names and we use naming conventions in the Philippines to establish ties between families through intermarriages. Following Padgett and McLean (2006) and Cruz, Labonne and Querubin (2017), we consider a tie between two families to exist whenever we observe at least one marriage between members of the two families. We graph the full family network in all villages in our sample. We then use community detection algorithms (Girvan and Newman, 2002; Pons and Latapy, 2005) to identify the configuration of clans in every village, based on the relative number of ties within and between clusters of families in the network. To account for the relative influence of each clan, we create a measure of social fractionalization with a Herfindahl index that captures how the village population is distributed across the different clans. We hypothesize that in less fractionalized or more cohesive villages, clan leaders are more effective in concentrating political influence and capturing politicians at the expense of public goods provision. Another implication of this is that more fractionalized villages will also feature higher political competition since clan heads will exert less persuasion and control over candidacy and the voting decisions of village residents.

Our results show that social fractionalization is positively correlated with village-level provision of public goods such as schools, public marketplaces, water systems and health centers. These correlations are sizable; for example, a one standard deviation increase in social fractionalization increases the probability that a health center is located in the village by around 6 percentage points (an increase of $10 \%$ relative to the sample mean). These correlations are robust to the inclusion of municipality fixed effects and a broad set of village covariates such as village population, the number of distinct families in the village, whether the village is classified as rural, as well as controls for different occupations and educational levels, amongst others. To address concerns about reverse causality (i.e. whether family ties, and thus our social fractionalization measures, are affected by public goods provision) we restrict our network to ties between individuals 45 years old or older, and use the social fractionalization measure in the restricted network - capturing marriages that 
took place at least 20 to 25 years ago - as an instrument for the corresponding measure in the full network. Our results are similar when we use this approach.

We also use two further approaches to establish that social fractionalization is correlated with stronger political competition. First, we use data on local sources of political influence from an original survey conducted in two provinces shortly after the 2013 election to show that, consistent with our theory, less fractionalized villages are characterized by a greater concentration of political influence. Second, we show that social fractionalization is associated with i) a larger number of candidates running for office in village elections and ii) narrower vote margins for the winning candidate in village and municipal elections.

Our results should be interpreted cautiously since naturally, social structure measures are not randomly assigned across villages. While we control for several village-level characteristics that may potentially confound our estimates, and follow an instrumental variables approach, we cannot fully account for all variables that may have shaped intermarriage networks over many decades. We show that fractionalization across clans is not correlated with preference heterogeneity or collective action and thus rule out these variables as mediators in our context. While political competition may partly mediate the effect of fractionalization on public goods (political competition and public goods provision are indeed positively correlated in our context), it may also be an outcome and there are other channels through which fractionalization may impact the redistributive strategies of politicians. Our findings point to the importance of considering how social structure shapes the concentration of power and the distributive strategies of politicians.

Much of the literature on public goods provision uses ethnic, linguistic, or religious fractionalization as a measure of social structure. This literature has shown mixed results, with many papers showing a negative relationship between fractionalization and public goods provision across both developed and developing countries (Easterly and Levine, 1997; Alesina, Baqir and Easterly, 1999; Miguel and Gugerty, 2005), while others question these correlations on both methodological and substantive grounds (Gao, 2016; Soifer, 2016; Wimmer, 2016; Kustov and Pardelli, 2018). We contribute to this literature in several ways. First, we argue that when politicians, rather than communities, are responsible for public goods provision, social cohesion may promote elite capture and lead to the under-provision of public goods. This is particularly relevant in clientelistic democracies where electoral strategies focus on the exchange of private transfers for electoral support. 
Second, we focus on a different measure of fractionalization based on a fundamental unit of social organization-the family-which may account for social structure even in countries where ethnic and religious fractionalization are not as relevant.

We also add to the literature on local elite capture - the concern that influential groups in the community with strong connections to local politicians disproportionately benefit from government resources - and the delivery of public goods (Bardhan, 2002). Our theory argues that patterns of elite capture can emerge endogenously as a function of the social structure and the electoral strategies of politicians. Our key contribution is that the political influence of different groups is a function of social fragmentation. We interpret the concentration of political influence, and the resulting under provision of public goods as a form of elite capture in our context. Closely related to our paper is the work by Acemoglu, Reed and Robinson (2014) who find that places in Sierra Leone with more ruling families exhibit better development outcomes today. In these places "chiefs constrained by greater competition will be less able to manipulate access to land for their own benefit or will have to compete by offering and providing public goods" (p. 321).

Our paper builds on a growing literature on the economic and political impact of families and kinship ties (Todd, 1985: Padgett and McLean, 2006: Moscona, Nunn and Robinson, 2017). In a closely related paper, $\mathrm{Xu}$ and Yao (2015) study the role of lineage groups on local governance in China. However, to our knowledge, our paper is the first to use large-scale family networks (based on the full sample of intermarriage ties for a large number of villages) to study how social structures influence the incentives of politicians to provide public goods.

We also contribute to the empirical literature on the role of social networks on the distributive strategies of politicians (Calvo and Murillo, 2009; Hughes, 2016; Larson and Lewis, 2017) and other political outcomes such as turnout (Eubank et al., 2017). We build on Cruz, Labonne and Querubin (2017) who show that a candidate's centrality in family networks facilitates brokered linkages with voters and contributes to higher vote shares during the elections. In this paper, rather than exploiting the position of individual candidates in the network, we study how the network structures of villages condition the distributive strategies of politicians.

Finally, we also contribute to the literature on social diversity and political competition. A series of studies have documented that greater social diversity leads to a larger number of parties and stronger political competition (Amorim-Neto and Cox, 1997; Potter, 2014, Lublin, 2017). This 
is consistent with our finding that greater fractionalization is associated with a larger number of candidates and less concentrated political influence.

\section{Theory: Social Structure, Public Goods and Electoral Competition}

Most existing theories on how social structures influence political and economic outcomes are based on studies documenting a negative correlation between ethnic or religious fractionalization and public goods provision (Easterly and Levine, 1997; Alesina, Baqir and Easterly, 1999). These theories emphasize how fractionalization may undermine collective action and the aggregation of policy preferences among citizens. These seem particularly relevant in contexts in which communities are responsible for the provision of public goods, for example through the payment of taxes or other contributions and must collectively agree on local priorities.

However, in most of the developing world, public goods are the responsibility of elected politicians rather than of communities. These public goods are often funded with transfers from the central government (not local taxes) and thus collective action and preference heterogeneity may be less relevant. In these contexts it becomes essential to understand how social structure shapes the distributive choices of politicians $1^{1}$

We argue that in weakly institutionalized democracies, where politicians are responsible for public service delivery, social cohesion can lead to an under provision of public goods. This is especially important in clientelistic contexts where voters engage with politicians through brokers and rely on information from friends, family, and neighbors in order to make political decisions. ${ }^{2}$

When members in a society are concentrated in a relatively small number of politically relevant groups, political influence- used here to refer to social persuasion and the ability to broker political exchange - also becomes more concentrated. As a consequence, leaders of larger groups have

\footnotetext{
${ }^{1}$ For example, Desmet, Ortuño-Ortín and Weber (2017) and Munshi and Rosenzweig (2018) study how diversity affects elected politicians' incentives to provide transfers vs. public goods. Similarly, Martinez-Bravo et al. (2012) show that voter religious heterogeneity constrains the potential benefits of elections for public goods provision.

${ }^{2}$ The importance of local political influence is not limited to the developing world. For example, Katz and Lazarsfeld (1955) show that individuals were most influenced by peers of similar social status. Similarly, research from surveys in the United States identify discussion networks (Huckfeldt and Sprague, 1991) and social cohesion (Huckfeldt et al. 1995) as important factors for the transmission of political information to citizens.
} 
high bargaining power and can demand private, targeted, excludable transfers to their group in exchange for the electoral support of its members. Transfers to these influential groups, which we interpret as a form of elite capture, crowd out and undermine the provision of public goods.

Social fractionalization can also increase the agency and transaction costs for politicians of engaging in the clientelistic exchange of private transfers for votes. Consider a society in which a large share of citizens belong to an handful of groups; in this case politicians can secure a large number of votes by brokering deals with a small number of influential leaders that they can more easily monitor. As the number of groups increases and each group represents a smaller share of the electorate, this electoral strategy becomes less attractive. Following Lizzeri and Persico (2004), as society becomes more fragmented, the incentives for politicians to provide policies with diffuse (as opposed to targeted and excludable) benefits increases, which can encourage the provision of public goods. This argument is also related to Dahl's theory on the benefits of pluralism and diversity for the performance of democracy (Dahl, 1973).

Finally, another implication of our theory is that less fractionalized villages will also feature lower political competition. First, clientelistic transfers become a more appealing strategy in these villages than providing public goods which will encourage clan leaders to mobilize voters in support of one of the candidates leading to both high turnout and less competitive races. Second, the concentration of political influence implies that clan leaders can mobilize a large set of voters over whom they exert influence in support of their preferred candidate. As a result we expect to observe a broader set of individuals running for public office and tighter races in more fractionalized villages. In the next section we illustrate some of these ideas in the Philippine context.

\subsection{Clans and Elections in the Philippines}

Local democracy in the Philippines is vibrant and highly relevant for studies of public service delivery (Rogers, 2004; Abinales and Amoroso, 2017). The country is divided into roughly 1,600 cities and municipalities which are themselves divided into over 42,000 barangays (villages). Municipalities are governed by a mayor, a vice-mayor and eight municipal councilors. All municipal officials are elected in first-past-the-post elections organized, by law, at fixed intervals of three years. Political parties tend to be weak and unstable, and there are typically large shifts in party affiliations after each election (Hutchcroft and Rocamora, 2003; Mendoza, Cruz and Yap, 2014). 
Every three years each barangay also elects a barangay captain (village head) and a barangay council. These are responsible for the maintenance of public goods and assisting the mayor with the implementation of municipal programs.

The 1991 Local Government Code devolved significant responsibilities for the delivery of a number of social services to municipalities, including primary health care programs, repair and maintenance of local infrastructure, and provision of agricultural, fishery, mines, and geoscience services (Azfar et al., 2000). Municipalities are expected to finance these services through yearly transfers from the central government, known as the Internal Revenue Allotment (IRA) (Llanto. 2012). While municipalities can also raise their own revenues through local taxes and fees, the IRA provides 85 percent of their budgets on average (Troland, 2016) $\mathrm{S}^{3}$

The mayor, as the chief executive of the municipal government, enjoys significant responsibilities and discretionary powers. Even in sectors with national-level programs such as education and health, the Local Government Code devolved responsibility for many client-facing services to the municipalities, as well as significant fiscal and regulatory functions (Llanto, 2012: Capuno, 2012). This is consistent with Rogers's (2004) characterization that for the day-to-day life of Filipinos, "government in every practical sense means local government." Mayors play an important role in deciding how to allocate the budget across various sectors and the different barangays that compose the municipality (Hutchcroft, 2012, Capuno, 2012).

At the same time, service delivery and public goods provision remains a challenge. For example, according to the 2010 Population Census, about 32 percent of villages do not have a health center and close to 40 percent do not have modern water and sanitation systems. Not surprisingly, health outcomes are also lacking. Under 5 infant mortality is about 28 per 1,000 live-births, higher than neighboring countries with lower income levels like Vietnam. About 33 percent of children under 5 are stunted, a rate similar to that of poorer countries in the region like Cambodia and Myanmar. This suggests that under provision of public goods is not only due to low income or lack of resources. In addition, the average municipality only spends 90 percent of its budget every year.

\footnotetext{
${ }^{3}$ These funds are disbursed in tranches, without conditions; while technically there is a requirement that at least $20 \%$ of funding should go towards development projects, the so-called Local Development Fund (LDF), this is not enforced in practice (Troland, 2016).
} 
These challenges are largely attributed to electoral incentives that center on clientelism rather than public goods provision (Timberman, 1991; Azfar et al., 2000; Khemani, 2015). This includes providing jobs (Lande, 1964; Fafchamps and Labonne, 2017), money (Khemani, 2015; Mendoza et al., 2016; Cruz, 2019), and other private goods and services (Hutchcroft and Rocamora, 2003) in exchange for political support. For example, surveys carried out in both urban and rural communities after the 2010 and 2016 elections suggest that around 30 percent of voters were offered money for their vote (Mendoza et al., 2016; Cruz, 2019). While clientelism can take different forms, the logistical requirements are substantial: the identification of clients and the delivery of benefits requires sophisticated networks to monitor actors and manage exchange relations (Kitschelt and Wilkinson, 2007) 4 Consequently, the practice of clientelism is predicated on social norms of reciprocal exchanges and obligations, which in the Philippines is reinforced by family ties (Corpuz. 1965: Enriquez, 1986; Miralao, 1997; Covar, 1998).

Taken together, it becomes easier to understand why Philippine political culture revolves around families and clans (Lande, 1964; Hutchcroft and Rocamora, 2003; McCoy, 2009; Abinales and Amoroso, 2017). Sidel (1999) attributes the importance of families in politics to the overlaying of democracy on the emerging socioeconomic landscape of hacienda-based clans and business elites ${ }^{5}$ There is even a commonly used Tagalog phrase that highlights the linkages between families and clientelism: kasal, binyag, libing, which literally means "weddings, baptisms, funerals." This wellknown term for clientelism refers to the fact that politicians are involved even in intimate family events, serving as godfathers for baptisms, sponsors for weddings, and contributing towards funeral costs.

Consequently, politicians competing in municipal elections must often seek the support of extended families, or clans (Timberman, 1991; Abinales and Amoroso, 2017). Fegan (2009) argues that families are key political actors because their reputation, loyalties, and alliances are transferable

\footnotetext{
${ }^{4}$ Even if vote buying is conducted as a one-off transaction, it still requires the ability to identify and contact voters, and in the context of a secret ballot, the means to ensure with reasonable certainty that voters will keep their end of the bargain once they are in the voting booth (Cruz, 2019).

${ }^{5}$ While families are perhaps the most common example of groups that can coordinate votes, they are certainly not the only ones: some religious and regional groups also use their ability to coordinate and enforce behavior to engage in group-level political exchange with politicians. A notable example is the religious group Iglesia ni Cristo, which endorses a slate of candidates that adherents are expected to vote for.
} 
from members who die or retire to the younger generations. One example is the norm of utang na loob (literally, "inner debt"), which refers to a debt of gratitude that fosters reciprocity and feelings of social obligation. As stated by Hollnsteiner (1963), "keeping with the highly familistic orientation of Philippine society whereby an individual represents his family, utang na loob is not limited to an individual-to-individual relationship but is rather seen as operative from family to family" (p.79). While we do not want to overstate the cultural basis for clans as political units, even conceptions of Filipino culture that would consider utang na loob as just a small part of a broader value framework would still emphasize the relational basis of Filipino values and the importance of the family unit for understanding politics (Enriquez, 1986; Aquino, 2004; Reyes, 2015). For example, Timberman (1991) cites the norms of utang na loob and pakikisama (ability to engage with others) as contributing to a personalistic and patronage-based political culture. Furthermore, while adherence to these traditional norms (as well as their social relevance) may decline over time, a recent study of Filipino adolescents conducted by Clemente et al. (2008) shows that the relational values identified by Enriquez (1986) - utang na loob, pakikisama, and hiya (shame as a result of unfulfilled social obligations) - were still considered to be important.

An implication of these features of Philippine society is that municipal politicians can often secure a large number of votes by targeting private transfers and services to members of large clans. These private transfers often come at the expense of the provision of public goods that would benefit all village residents equally. Clan heads, together with barangay officials, often operate as brokers between municipal candidates and clan members, monitoring that clans vote as promised and that resources flow to the families. While in some instances clan members can only imperfectly command the votes of their clan, the shared expectations and norms of reciprocity among clan members give them organizational advantages for engaging in political exchange.

\section{Identifying Clans and Measuring Fractionalization}

\subsection{Clans and Communities}

An empirical challenge in our context is characterizing the social structure in every village. Key to our analysis is determining the number of politically relevant clans in each village. Theoretically, for our purposes a clan is a set of families: (i) connected to each other by kinship or marriage; 
and (ii) where relationships of exchange among members are governed by well-established norms of cooperation and reciprocity. In other words, they are the set of individuals for whom existing familial ties can facilitate coordination of votes for the politician that provides patronage or transfers to the clan. While individuals in the Philippines can easily provide us with this information, absent detailed village-level surveys it is very hard to collect this data at a large scale. We propose to use social network analysis to address this issue, by identifying cohesive groups of families in the inter-marriage network. Cohesive groups are those with many ties within the group and relatively fewer ties to other groups.

Consider a social network in which a node is a family and edges between nodes imply that a marriage has occurred between members of these families. An example is illustrated in panel a) of Figure 1 that shows a network with 15 different families. This network features three components, that is, groups within which nodes are path-connected, but disconnected from other sets of nodes in the network (Jackson, 2010). One intuitive approach would be to identify each different clan with the different components in the marriage network. This approach, while appealing, can be quite restrictive in practice since family networks in real life (and in our Filipino context, in particular) rarely feature neatly distinct components as those illustrated in panel a).

By contrast, the slightly modified network in panel b) of Figure 1 differs only from panel a) in that we have added two additional edges (represented by dashed lines): one between families A and $\mathrm{K}$ and another one between families I and $\mathrm{M}$. The three distinct sets of nodes are still apparent, but this modified network has only one component (the full network). Thus, an approach based on components would identify only one clan in this network and all individuals would belong to that clan. An alternative that considers both the distinct sets of nodes but also the additional links among them is the concept of communities. In a social network, communities are groups of nodes with dense connections internally (i.e. within the group) and sparser connections between groups (Jackson, 2010). Intuitively, the social network in panel b) has three different communities even though it has only one component.

Our approach is thus to use the different communities in the social networks as proxies for the clans. At the same time, the community structure in a network is a latent feature that needs to be uncovered; there are several potential ways to partition a network's nodes into separate groups that we describe in the following section. 


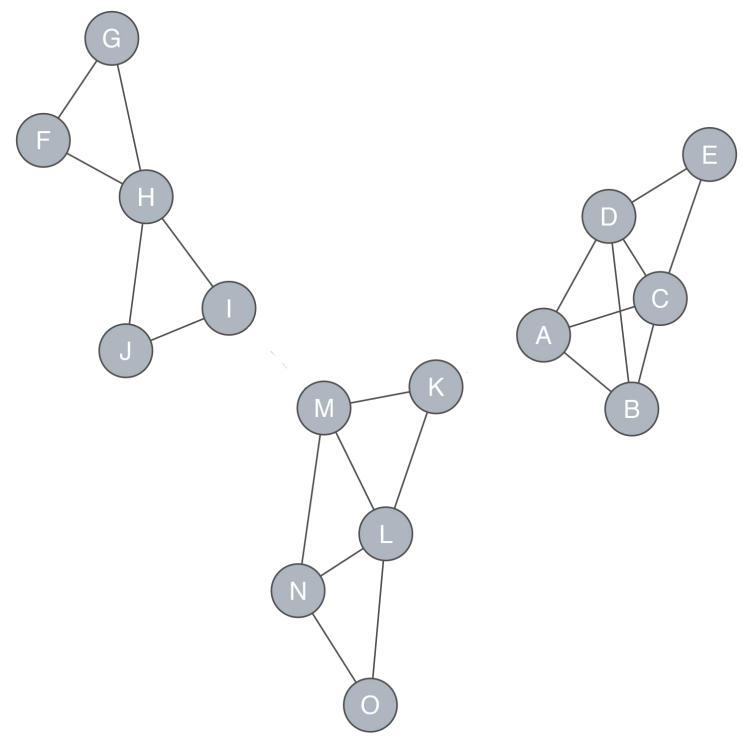

Panel a): Network with 3 components

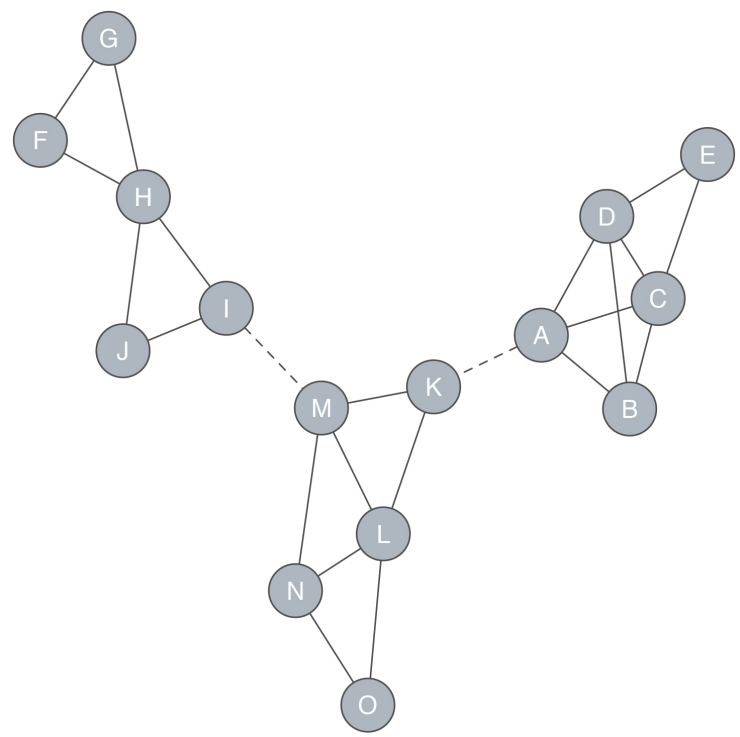

Panel b): Network with 1 component

Figure 1: Sample marriage networks. Nodes represent families and edges indicate a marriage between those families

\subsection{Community Detection}

One approach to uncovering community structures in social networks is based on edge removal. The intuition is as follows: if two groups of nodes are only loosely connected with each other, then removing the edges between those two groups will generate components in the restricted network. Communities correspond to those components in the restricted network. The networks in Figure 1 can be used to illustrate this approach. The two dashed edges in panel b) loosely connect groups of nodes that are densely connected with each other. Removing those two edges will yield a restricted network like the one illustrated in panel a) with three different components.

Approaches based on edge removal differ in terms of the selection rule regarding which edges to remove. We follow an algorithm proposed by Girvan and Newman (2002) that consists in the sequential removal of edges with high betweenness centrality. This centrality measure captures the extent to which the edge serves as a link between different groups. It is calculated using the number of shortest paths between nodes in the network that pass through that edge ${ }^{6}$ For example, the dashed edge between nodes $\mathrm{J}$ and $\mathrm{E}$ in Figure 2 has the highest betweenness centrality in that network. Similarly, the dashed edges in panel b) of Figure 1 have high betweenness centrality.

\footnotetext{
${ }^{6}$ For more information on calculating betweenness centrality, please refer to Appendix A.
} 


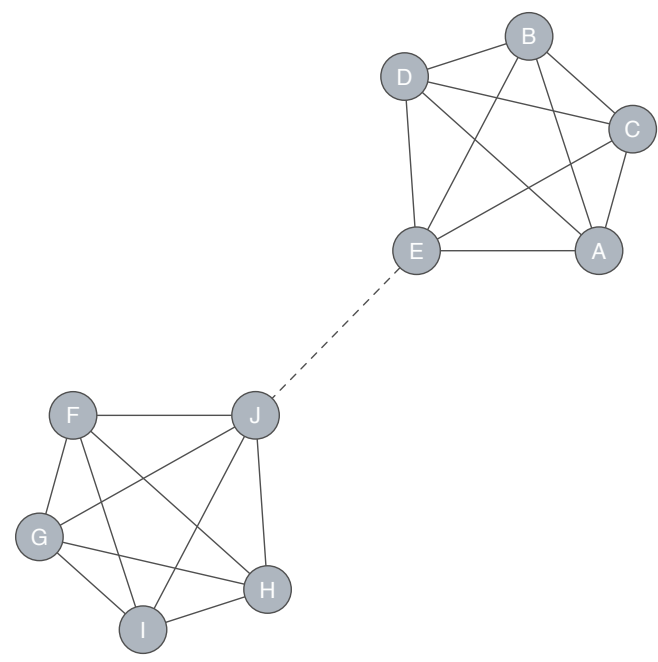

Figure 2: Edge with High Betweenness Centrality

The Girvan-Newman algorithm proceeds as follows:

1. Calculate betweenness for all edges in the network

2. Remove the edge with the highest betweenness

3. Recalculate betweenness for all edges affected by the removal

4. Repeat from step 2 until no edges remain

5. From resulting dendrogram (the hierarchical mapping produced by gradually removing these edges), select the partition that maximizes network modularity (characterized by dense connections within clusters and sparse connections between them)

While in our baseline analysis we focus on communities identified by the Girvan-Newman algorithm, for robustness we also implement the walktrap algorithm developed by Pons and Latapy (2005). Intuitively, the algorithm relies on the idea that random walks on a graph tend to get "trapped" into densely connected parts corresponding to communities. The algorithm thus generates a large number of random walks and groups together nodes that are tied together through those walks. See Pons and Latapy (2005) for more details.

\subsection{Measuring fractionalization}

The algorithm delivers a partition of $C$ communities (indexed by $c=1, \ldots, C$ ), each containing a share $s_{c}$ of distinct families. We then use this to compute our main independent variable, the 
measure of social fractionalization $(S F)$, using a standard Herfindahl-Hirschman index:

$$
S F=1-\sum_{c=1}^{C} s_{c}^{2}
$$

The measure can be interpreted as the probability that two randomly selected families are from different clans. We use this approach because we are interested in accounting for both the overall configuration of clans in the village, as well as differences in relative size or strength among clans.7

\section{Data}

In this section we present our various data sources and describe our main dependent and independent variables.

\subsection{Family networks}

Our main independent variable is the extent to which a village's population is fragmented into several clans. To do this we identify network communities and use them as proxies for clans in the family network of the village. To construct the family networks, we use data collected for the National Household Targeting System for Poverty Reduction (NHTS-PR). This large-scale household-survey, implemented between 2008 and 2010, reports several socio-economic characteristics of the household as well as the gender, age, educational attainment and occupational category of every household member. We focus on municipalities where full enumeration took place ${ }^{8}$ This leaves us with information on 20 million individuals in about 15,000 barangays in 709 municipalities.$^{9}$ Importantly, we have access to the non-anonymized version of the dataset and

\footnotetext{
${ }^{7}$ By contrast, other measures of social structure tend to focus on one or the other: for example, connectedness is measured by density measures, while variance in connectedness among actors is measured using centralization measures (essentially the distribution of centrality in the network).

${ }^{8}$ Importantly, we do not use a sampled network to detect our communities and as such our analysis does not suffer from the problems identified by Chandrasekhar and Lewis (2011). In the remaining municipalities, only households in so-called pockets of poverty were interviewed.

${ }^{9}$ As shown in Table A.1. villages in our sample are, on average, less populated and more rural than the national average. There are no major differences in other socio-economic characteristics such as ethnic and religious fragmentation
} 
have two family names (the middle and last name) for every individual 10

We are able to measure large scale family networks in the Philippines due to naming conventions with two convenient features: (i) within a municipality, a shared family name implies family connections; (ii) each individual carries two family names, which establishes that a marriage took place between members of those two families.

More concretely, names in the Philippines have the following structure:

\section{firstname midname lastname}

where firstname corresponds to the individual's given first name, midname corresponds to the mother's maiden name (for men and single women) or the father's family name (for married women) and lastname corresponds to the father's family name (for men and single women) or the husband's family name (for married women).

The naming structure and distribution of family names in the Philippines can be traced back to the 19 th century. In 1849, concerned with the arbitrary way in which Filipinos chose their surnames and the implications for tax collection, Governor Narciso Claveria y Zaldua created a catalog with a list of 61,000 different surnames. Municipal officials throughout the country then assigned a different name to each family. Since then, names have been transmitted through generations according to well-established and enforced naming conventions. As a consequence very common family names are not as prevalent in the Philippines as in other countries and thus, sharing a family name is very strongly correlated with an actual family tie. This is especially the case within municipalities and villages.

Given the full names of all individuals in an area, we are able to reconstruct all of the edges in the family network by examining the joint occurrences of middle and last names ${ }^{11}$ As noted above, each individual maintains two family names: their father's name and either their mother's maiden name or their husband's name, in the case of married women. Thus each individual's set of family names indicates an intermarriage between the two families-either in their generation (in the case of married women) or their parents' generation (in the case of men and single women). As

or public goods provision. Our sample is representative of rural villages in the Philippines.

${ }^{10}$ Fernandez (2012) describes the data in more detail.

${ }^{11}$ A similar method is used by Cruz, Labonne and Querubin (2017), Haim (2018) and Rubin (2018). 
a result, we are able to observe ties between families merely by the occurrence of the family names within an individual.

For example, Figure 3 below depicts the family network that can be drawn from a list of relatives of the previous Philippine President, Benigno Cojuangco Aquino. His middle name is his mother's maiden name, Cojuangco, and his last name is his father's last name, Aquino, implying a marriage tie between the Cojuangco and Aquino families. Similarly, we can show ties between the Aquino, Abellada, and Aguirre families through the names of his sister Aurora Aquino Abellada and cousin Bam Aguirre Aquino. On the Cojuangco side, we can show ties to the Sumulong and Teodoro families through the names of his cousin Gilberto Cojuangco Teodoro and uncle Jose Sumulong Cojuangco, as well as an indirect tie to the Prieto family through Gilberto's wife Monica Prieto Teodoro.

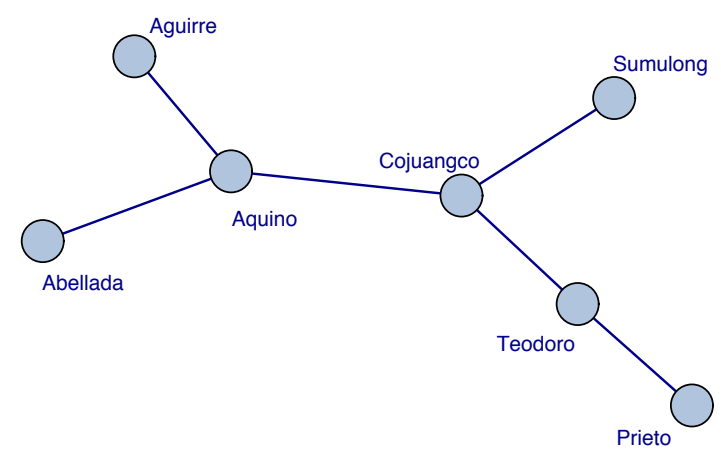

Figure 3: Family network for selected members of former President Aquino's family.

Once the networks are constructed, we implement the Girvan-Newman and walktrap algorithms and as discussed in Section 3, we then compute our main independent variable, the measure of social fractionalization $(S F)$.

Table A.2 presents some descriptive statistics on the number of communities and fractionalization measures. The average (median) number of communities per village is 46 (34). However, the two largest communities in the village contain, on average, close to $25 \%$ of the village population. While more populated villages exhibit higher fractionalization, there is substantial variation in fractionalization across villages in all terciles of the population distribution. Below we show that our estimates are robust to controlling for village population and to dropping villages with extreme fractionalization and population values. 


\subsection{Outcome Variables}

\subsubsection{Public Goods}

For our main outcome, we use data from the 2010 population census that lists public goods available in every barangay. We use this to code dummies for whether the barangay has an elementary school, a high school, a public market, a health center or a community water system. Since our indicators all capture the same concept, to address the multiple comparisons problem, we combine them into a public goods index using the inverse covariance weighting approach proposed by Anderson (2008) 12 Table A.2 provides some descriptive statistics for our different outcome variables.

\subsubsection{Preference Heterogeneity and Collective Action}

We use data from from a survey conducted shortly after the 2013 local elections to examine the extent to which social fractionalization is correlated with heterogeneity in preferences over public goods and collective action. ${ }^{13}$ Previous studies argue that these variables play an important role in understanding the effect of fractionalization on public goods provision.

More specifically respondents were asked about their preferred allocation of the municipality's Local Development Fund (LDF) across 10 different sectors ${ }^{14}$ As a measure of heterogeneity in preferences, we simply take the standard deviation in respondents preferred allocation for each budget item.

To measure social capital and collective action we simply use dummy variables for whether the household participated in any formal group (such as unions, farmer's or other professional associations, community development associations, micro finance groups and cooperatives) or in communal voluntary work activities (known locally as bayanihan) and average those over all village

\footnotetext{
${ }^{12}$ The computations are described in Appendix A.1.3.

${ }^{13}$ The survey covers 3,408 households in 284 villages in 12 municipalities in the provinces of Ilocos Norte and Ilocos Sur.

${ }^{14}$ The 10 sectors on which we have data are: public health services, public education services, cash or in-kind transfers (such as loans or job assistance), water and sanitation services, road construction and rehabilitation, construction of community facilities (such as multipurpose halls or basketball courts), business loans and other private economic development programs, agricultural assistance and irrigation systems, peace and security and community events and festivals.
} 
respondents.

\subsubsection{Political Competition}

To examine the correlation between social fractionalization and political competition we use electoral outcomes from the 2010 municipal elections and the 2010 and 2013 barangay elections collected from the Commission of Elections (COMELEC) website. For municipal elections, we have precinctlevel data on the number of registered voters, the number of individuals who voted and the number of votes received by each mayoral candidate ${ }^{15}$ For barangay-level elections, we have village-level data on the votes obtained by every candidate for barangay head (punong barangay) and for the barangay council (barangay kagawad).

Our main political competition variables are the win margin (vote share of the candidates that received the most votes in that precinct minus vote share of the runner-up in that precinct) and the number of candidates running in the race. We also use indices of effective number of candidates, proposed by Laakso and Taagepera (1979) and Golosov (2010) and described in the Appendix. As above, we combine these measures into a single political competition index following Anderson (2008).

To capture the effects on the concentration of political influence we also use the 2013 survey. Respondents were asked to "name five individuals living in the barangay, but not living in your household, whose opinions you respect the most when it comes to politics." This allows us to test whether social fractionalization affects the overall number of influential leaders that villagers mention in their responses.

\section{Empirical Analysis and Results}

Our main analysis consists of village-level cross-sectional regressions between public goods and political competition outcomes and our index of social fractionalization. More concretely, we estimate OLS regressions of the form:

\footnotetext{
${ }^{15}$ In the Philippines there is at least one precinct per village, so we can perfectly merge our electoral, public goods and social networks data.
} 


$$
y_{v m}=\alpha+\beta S F_{v m}+\gamma X_{v m}+\delta_{m}+\epsilon_{v m}
$$

where $y_{v m}$ is the outcome variable in village $v$ in municipality $m, S F_{v m}$ is our measure of social fractionalization, $X_{v m}$ corresponds to a full set of village covariates and $\delta_{m}$ is a full set of municipality fixed-effects. Standard errors are clustered at the municipality level.

The inclusion of municipality fixed effects is important in this context since they allow us to absorb all municipality-specific characteristics that may be correlated with both social fractionalization and our different outcome variables. Moreover, we are interested in how mayors adjust their electoral and distributive strategies across the different villages in their municipality as a function of the level of social fractionalization. Thus, we are interested in exploiting within-municipality variation. For ease of interpretation, in all regressions we include a standardized version (mean zero, standard deviation one) of the social fractionalization index.

\subsection{Public Goods}

We begin by estimating the correlation between social fractionalization and the public goods index, as well as dummies for the presence of each of the different public goods in the village. Estimates of $\beta$ are reported in Panel A of Table 1 . The coefficients reveal a positive and statistically significant correlation between social fractionalization and public goods provision. For example, a one-standard deviation increase in social fractionalization is associated with an increase of 0.21 standard deviations in the public goods index. Looking at the individual public good dummies, a one-standard deviation increase in social fractionalization is associated with an increase in 8 percentage points in the likelihood of having a secondary school in the village, and a 6 percentage point increase in the likelihood of having a public market or a health center in the village. Some of these estimates are sizable; relative to the mean they correspond to an increase of $40 \%$ for high schools, $30 \%$ for public markets and 10\% for health centers and waterworks. However, these coefficients must be interpreted very cautiously since social fractionalization is not randomly assigned across villages. While municipality fixed effects account for municipal-level confounders, omitted variable bias remains a concern since other village characteristics may be correlated with social fractionalization and public goods provision. For example, larger, heavily populated, urban 
villages that feature higher social fractionalization may be more likely to have public goods. It may also be the case that wealthier villages feature greater fractionalization and can use their resources to secure more public goods from politicians. Finally, reverse causality may also be a concern: there may be higher migration into villages with a larger supply of public goods, and new migrants may generate more social fractionalization (i.e. more disperse marriage networks).

To deal with this concern, we follow two approaches. First, we control for a wide range of village characteristics. To deal with potential demographic confounders we include average age, gender ratio, village population, and the number of distinct families in the village. We also include average length of stay in the village which may account for differential migration patterns. To control for economic characteristics of the village we control for a dummy indicating whether the village is classified as rural, as well as population in each of 17 educational and 11 occupational categories, average per capita income and poverty incidence. The estimates of $\beta$ once we include this set of controls are reported in Panel B of Table 1. The point estimates become smaller but remain statistically significant at conventional levels and substantively large for some outcomes (for example, a one standard deviation increase in fractionalization leads to a $10 \%$ increase in the likelihood of having a high school or market in the village) 16

\footnotetext{
${ }^{16}$ Please note that with our full set of controls the $p$-values for each of the 5 components of the public goods index are below .01. Thus, even a very conservative Bonferroni correction would lead us to reject the null of no effects for all the outcomes at the 5 percent level.
} 
Table 1: Network Fractionalization and Public Goods Provision

\begin{tabular}{|c|c|c|c|c|c|c|}
\hline & $\begin{array}{c}(1) \\
\text { Index }\end{array}$ & $\begin{array}{c}(2) \\
\text { Elem. School }\end{array}$ & $\begin{array}{c}\text { (3) } \\
\text { High School }\end{array}$ & $\begin{array}{c}\text { (4) } \\
\text { Market }\end{array}$ & $\begin{array}{c}(5) \\
\text { Health Center }\end{array}$ & $\begin{array}{c}\text { (6) } \\
\text { Waterworks }\end{array}$ \\
\hline \multicolumn{7}{|c|}{ Panel A: No Controls } \\
\hline Fractionalization & $\begin{array}{l}0.12^{* *} \\
(0.02)\end{array}$ & $\begin{array}{l}0.01^{*} \\
(0.01)\end{array}$ & $\begin{array}{l}0.08^{* *} \\
(0.01)\end{array}$ & $\begin{array}{l}0.06^{* *} \\
(0.01)\end{array}$ & $\begin{array}{l}0.06^{* *} \\
(0.01)\end{array}$ & $\begin{array}{l}0.05^{* *} \\
(0.01)\end{array}$ \\
\hline Observations & 15,464 & 15,449 & 15,449 & 15,449 & 15,449 & 15,449 \\
\hline R-squared & 0.040 & 0.001 & 0.027 & 0.020 & 0.014 & 0.010 \\
\hline Mean Dep. Var. & 0 & 0.806 & 0.209 & 0.190 & 0.639 & 0.597 \\
\hline Std. Dev. Dep. Var. & 0.571 & 0.395 & 0.407 & 0.392 & 0.480 & 0.490 \\
\hline \multicolumn{7}{|c|}{ Panel B: Full Controls } \\
\hline Fractionalization & $\begin{array}{l}0.05^{* *} \\
(0.01)\end{array}$ & $\begin{array}{l}0.03^{* *} \\
(0.01)\end{array}$ & $\begin{array}{l}0.02^{* *} \\
(0.01)\end{array}$ & $\begin{array}{l}0.02^{* *} \\
(0.00)\end{array}$ & $\begin{array}{l}0.03^{* *} \\
(0.01)\end{array}$ & $\begin{array}{l}0.02^{* *} \\
(0.01)\end{array}$ \\
\hline Observations & 15,445 & 15,432 & 15,432 & 15,432 & 15,432 & 15,432 \\
\hline R-squared & 0.169 & 0.075 & 0.172 & 0.139 & 0.049 & 0.037 \\
\hline Mean Dep. Var. & 0 & 0.806 & 0.209 & 0.190 & 0.639 & 0.597 \\
\hline Std. Dev. Dep. Var. & 0.571 & 0.395 & 0.407 & 0.392 & 0.480 & 0.490 \\
\hline
\end{tabular}

Notes: Results from village-level regressions with municipal fixed-effects. The dependent variable is an index (Column 1) capturing the availability of key public goods at the village-level (elementary schools, high schools, markets, health centre and water systems), a dummy equal to one if there is an elementary school in the village (Column 2), a high school in the village (Column 3), a market in the village (Column 4), a health center in the village (Column 5) and a waterworks system in the village (Column 6). In Panel B regressions control for village-level average age, average length of stay in the village, gender ratio, village population, the number of distinct families in the village, whether the village is classified as rural, as well as education levels in the village, occupation in the village and average per capita income and poverty incidence. Standard errors (in parentheses) are clustered by municipality. ${ }^{*} \mathrm{p}<0.05,{ }^{* *} \mathrm{p}<.01$.

Our second approach to address concerns of endogeneity and reverse causality is to construct networks based on individuals aged 45 or older. These networks would mostly reflect marriage decisions made prior to when public goods are observed (i.e. a generation earlier) and thus the social fractionalization measures based on these networks are less likely to reflect reverse causality. All our subsequent robustness checks are reported only for the public goods index and include the full set of village controls ${ }^{17}$ In Column 1 of Table 2 we report the reduced form (OLS) estimate using the social fractionalization index from the network restricted to those 45 and older while in Column 2 we instead use the social fractionalization index in the restricted network as an instrument for social fractionalization in the full network and report the 2SLS estimate of $\beta$. Both point estimates

\footnotetext{
${ }^{17}$ Results are very similar for each of the public goods dummies separately.
} 
are positive and statistically significant. In Table 2 we also report the robustness of our estimates to different ways of constructing our fractionalization measure where $s_{\mathcal{C}}$ is the share of villagers who belong to community c (column 3) or the share of voting age villagers who belong to the community (column 4) or using the walktrap algorithm to identify the set of communities (clans) in every village (Column 5). The point estimates remain essentially unchanged which suggests our estimates do not depend on our particular choice of community detection algorithm.

Table 2: Robustness to Alternative Fractionalization Measures

\begin{tabular}{lccccc}
\hline \hline & $(1)$ & $(2)$ & $(3)$ & $(4)$ & $(5)$ \\
\hline & \multicolumn{2}{c}{ Over 45 } & \multicolumn{2}{c}{ Communities Weighted By: } & Walktrap \\
& OLS & IV & Share Villagers & Share Voters & Algorithm \\
\hline Fractionalization & $0.06^{* *}$ & $0.11^{* *}$ & $0.06^{* *}$ & $0.06^{* *}$ & $0.05^{* *}$ \\
& $(0.01)$ & $(0.02)$ & $(0.01)$ & $(0.01)$ & $(0.01)$ \\
& & & & & \\
Observations & 15,441 & 15,441 & 15,445 & 15,445 & 15,445 \\
R-squared & 0.171 & & 0.170 & 0.170 & 0.171 \\
\hline
\end{tabular}

Notes: Results from village-level regressions with municipal fixed-effects (OLS in Columns 1, 3-5 and 2SLS in Column 2). The dependent variable is an index capturing the availability of key public goods at the village-level (elementary schools, high schools, markets, health centre and water systems). In Column 1 the fractionalization measure is computed using communities obtained on the network restricted to individuals over the age of 45 . In Column 3, the fractionalization measure weights each community by its share of villagers. In Column 4 , the fractionalization measure weights each community by its share of villagers aged 18 or older. In Column 5, the fractionalization measure is computed using communities obtained with the walktrap algorithm. Regressions control for village-level average age, average length of stay in the village, gender ratio, village population, the number of distinct families in the village, whether the village is classified as rural, as well as education levels in the village, occupation in the village and average per capita income and poverty incidence. Standard errors (in parentheses) are clustered by municipality. ${ }^{*} \mathrm{p}<0.05,{ }^{* *}$ $\mathrm{p}<.01$.

We report additional robustness checks in Tables A.3 A.5. In Table A.3 we show that our results are robust to dropping villages in the top and bottom $1 \%$ and $5 \%$ of the fractionalization (Columns 1-2) and population (Columns 3-4) distributions. This suggests that our findings are not driven by villages with extremely high or low values of population or social fractionalization. In Table A.4 we also show that our estimates are robust to: dropping urban areas (Column 1), dropping the village where the largest number of relatives of the incumbent mayor reside (Column 2) and dropping municipalities in the Autonomous Region of Muslim Mindanao (ARMM), a majority muslim region and one of the poorest in the country (Column 3). Finally, we also show that our estimates remain relatively unchanged when we control for characteristics of the incumbent and 
the challengers' families in the village (Columns 4 and 5) 18 This addresses the concern that more fragmented villages are more likely to house immediate relatives of politicians and this is what drives the higher provision of public goods.

The Philippines is a relatively ethnically and religiously homogenous country (although it is very linguistically diverse-easily in the top 20 in the world and the highest in Asia), and thus our measure of social fragmentation is unlikely to capture fragmentation across these two dimensions. One potential external validity concern is that our measure of social fractionalization is only relevant in an ethnically or religiously homogenous setting like the Philippines, a natural concern in withincountry studies. However, at the level of analysis of the village, the Philippines even more closely resembles more ethnically fragmented countries. For example, comparing village-level data from Tajima, Samphantharak and Ostwald (2018), while there are notable differences in ethnic diversity between Indonesia and the Philippines at the national level, these differences all but disappear at the village level (Table 3). In other words, even if the Philippines may seem to be an outlier in terms of ethnic diversity at the national level, in terms of the actual villages and communities we study, Philippine villages look very much like villages across the developing world in terms of ethnic diversity.

Furthermore, we do not think that our results are merely capturing the role of ethnic diversity. In fact, in Column 6 of Table A.4 we show that our point estimate for social fractionalization remains unchanged when we control for Herfindahl indices for ethnic and religious fractionalization. In addition, in Table A.5 we show that the correlation between fractionalization and public goods provision is statistically significant and of similar magnitude in villages above or below the median value of ethnic or religious fractionalization (Columns 1 and 2) ${ }^{19}$ Our estimate is also similar when we restrict the analysis to ARMM (Column 3).

In sum, our results provide evidence of a positive correlation between social fractionalization and public goods provision. As previously highlighted, a key feature of our setting, of broader theoretical and empirical relevance, is that public goods provision in the Philippines is not the

\footnotetext{
${ }^{18}$ These include the politician's number of relatives, number of females relatives, number of relatives in each education/occupation category and eigenvector centrality of the family.

${ }^{19}$ Average ethnic fractionalization in above median villages is 0.35 , substantially higher than in the average Indonesian village, for example.
} 
Table 3: Comparing Ethnic Diversity in the Philippines and Indonesia

\begin{tabular}{|l|c|c|}
\hline & Philippines & Indonesia \\
\hline Country level (Alesina et. al. 2003) & .239 & .735 \\
Country level (Fearon 2003) & .161 & .766 \\
Village level & .180 & .183 \\
\hline
\end{tabular}

Notes: National level ethnic fractionalization measures for the Philippines and Indonesia, from Alesina et al. (2003) and Fearon (2003). Village level figures from Tajima, Samphantharak and Ostwald (2018) (Indonesia) and authors' calculations (Philippines). Village-level data from the Philippines refers to villages in our sample.

responsibility of local communities but rather of politicians with funds transferred by the central government. In these settings, the risk of elite capture becomes particularly important and collective action or heterogenous preferences may become less relevant. We explore this directly in Tables 4 and 5 where we show respectively that: i) more fractionalized villages do not exhibit more heterogenous preferences over 10 different public goods categories, as measured by the standard deviation of respondent's average desired budget share on each item; ii) social fractionalization is not robustly correlated with collective action as measured by participation in voluntary work (bayanihan) or membership in groups and civil associations 20

\footnotetext{
${ }^{20}$ The municipalities in which we conducted our surveys are not part of the NHTS-PR sample. Thus, to generate social networks we rely on the lists (family names) of registered voters in every village. However, network statistics based on NHTS-PR yield relatively similar results to those based on registered voter lists.
} 
Table 4: Network Fractionalization and Preferences over Public Goods

\begin{tabular}{|c|c|c|c|c|c|c|c|c|c|c|}
\hline & $\begin{array}{c}\text { (1) } \\
\text { Health }\end{array}$ & $\begin{array}{c}\text { (2) } \\
\text { Education }\end{array}$ & $\begin{array}{c}\text { (3) } \\
\text { Emergencies }\end{array}$ & $\begin{array}{c}(4) \\
\text { Water }\end{array}$ & $\begin{array}{c}(5) \\
\text { Road }\end{array}$ & $\begin{array}{c}\text { (6) } \\
\text { Com. Faci. }\end{array}$ & $\begin{array}{c}(7) \\
\text { Econ. Prog. }\end{array}$ & $\begin{array}{c}(8) \\
\text { Agriculture }\end{array}$ & $\begin{array}{c}(9) \\
\text { Peace }\end{array}$ & $\begin{array}{c}(10) \\
\text { Festivals }\end{array}$ \\
\hline \multicolumn{11}{|c|}{ Panel A: No Controls } \\
\hline Fractionalization & $\begin{array}{l}-0.05 \\
(0.53)\end{array}$ & $\begin{array}{l}-0.29 \\
(0.35)\end{array}$ & $\begin{array}{l}-0.21 \\
(0.30)\end{array}$ & $\begin{array}{l}-0.50^{*} \\
(0.22)\end{array}$ & $\begin{array}{l}-0.00 \\
(0.25)\end{array}$ & $\begin{array}{c}0.15 \\
(0.07)\end{array}$ & $\begin{array}{c}0.19 \\
(0.32)\end{array}$ & $\begin{array}{l}-0.33 \\
(0.30)\end{array}$ & $\begin{array}{l}-0.14 \\
(0.13)\end{array}$ & $\begin{array}{l}-0.04 \\
(0.10)\end{array}$ \\
\hline Observations & 283 & 283 & 283 & 283 & 283 & 283 & 283 & 283 & 283 & 283 \\
\hline R-squared & 0.000 & 0.002 & 0.002 & 0.020 & 0.000 & 0.005 & 0.001 & 0.002 & 0.004 & 0.000 \\
\hline Mean Dep. Var. & 11.19 & 11.19 & 8.285 & 7.425 & 6.836 & 5.526 & 7.798 & 15.14 & 5.855 & 4.064 \\
\hline \multicolumn{11}{|c|}{ Panel B: Full Controls } \\
\hline Fractionalization & $\begin{array}{c}0.05 \\
(0.51)\end{array}$ & $\begin{array}{l}-0.20 \\
(0.35)\end{array}$ & $\begin{array}{l}-0.09 \\
(0.30)\end{array}$ & $\begin{array}{l}-0.51^{*} \\
(0.22)\end{array}$ & $\begin{array}{c}-0.03 \\
(0.27)\end{array}$ & $\begin{array}{c}0.12 \\
(0.07)\end{array}$ & $\begin{array}{c}0.28 \\
(0.29)\end{array}$ & $\begin{array}{l}-0.29 \\
(0.32)\end{array}$ & $\begin{array}{c}-0.12 \\
(0.11)\end{array}$ & $\begin{array}{l}-0.03 \\
(0.09)\end{array}$ \\
\hline Observations & 283 & 283 & 283 & 283 & 283 & 283 & 283 & 283 & 283 & 283 \\
\hline R-squared & 0.082 & 0.066 & 0.118 & 0.057 & 0.023 & 0.043 & 0.065 & 0.071 & 0.049 & 0.011 \\
\hline Mean Dep. Var. & 11.19 & 11.19 & 8.285 & 7.425 & 6.836 & 5.526 & 7.798 & 15.14 & 5.855 & 4.064 \\
\hline
\end{tabular}

Notes: Results from village-level regressions with municipal fixed-effects. The dependent variable is the standard deviation in the budget share that voters in the village would like to spend on Health (Column 1), Education (Column 2), Emergencies (Column 3), Water (Column 4), Roads (Column 5), Community Facilities (Column 6), Business Loans (Column 7), Agriculture (Column 8), Security (Column 9) and Community Events/Festivals (Column 10). In Panel B regressions control for village population, whether the village is classified as rural, average education, age, household size, and length of residence, as well as the share of population that is female, receives remittances from abroad, and benefits from a CCT program. Standard errors (in parentheses) are clustered by municipality. ${ }^{*} \mathrm{p}<0.05,{ }^{* *} \mathrm{p}<.01$.

Table 5: Network Fractionalization and Collective Action

\begin{tabular}{lcccc}
\hline & $(1)$ & $(2)$ & $(3)$ & $(4)$ \\
& \multicolumn{2}{c}{ Bayanihan } & \multicolumn{2}{c}{ Group } \\
\hline Fractionalization & 0.02 & 0.02 & -0.01 & -0.01 \\
& $(0.01)$ & $(0.01)$ & $(0.01)$ & $(0.01)$ \\
& & & & \\
Controls & No & Yes & No & Yes \\
Observations & 283 & 283 & 283 & 283 \\
R-squared & 0.008 & 0.092 & 0.002 & 0.128 \\
Mean Dep. Var. & 0.751 & 0.751 & 0.658 & 0.658 \\
\hline
\end{tabular}

Notes: Results from village-level regressions with municipal fixed-effects. The dependent variable is the share of households that participates in voluntary work (Columns 1-2) and the share of households that is a member of a formal group (Columns 3-4). In Columns 2 and 4, regressions control for village population, whether the village is classified as rural, average education, age, household size, and length of residence, as well as the share of population that is female, receives remittances from abroad, and benefits from a CCT program. Standard errors (in parentheses) are clustered by municipality. ${ }^{*} \mathrm{p}<0.05,{ }^{* *} \mathrm{p}<.01$.

\subsection{Political Competition}

We hypothesize that social fractionalization can limit the ability of clan heads to effectively deliver a large number of votes in exchange for private transfers which in turn provides incentives for 
mayors to provide more public goods in these areas. An additional implication of our theory is that more fractionalized villages will also feature higher political competition since clan heads will have a weaker influence over candidacy and voting decisions of village residents.

First, we provide evidence that higher social fractionalization undermines the ability of a small set of elite members (for example, clan leaders) to exercise disproportionate influence on the political choices of village residents. To study this, we consider the number of politically influential individuals mentioned by village respondents in our 2013 survey ${ }^{21}$ We consider both the raw number of individuals nominated as well the effective number of nominees (where we take into account the number of mentions). The estimates reported in Table 6 suggest that political influence is less concentrated in highly fragmented villages: a one standard deviation increase in social fractionalization is associated with approximately one additional politically influential leader.

\footnotetext{
${ }^{21}$ The surveys were pilot tested to ensure that the questions were capturing personalized political influence within communities and not national media or politicians. Indeed, respondents were overwhelmingly reporting their local village elected officials as politically influential, accounting for $47 \%$ of the responses. Consistent with the notion of social persuasion, the rest are personal connections of the respondent: family members and friends/neighbors are $20 \%$ and $29 \%$ of responses, respectively.
} 
Table 6: Network Fractionalization and Politically Influential Individuals

\begin{tabular}{lccc}
\hline \hline & $(1)$ & $(2)$ & $(3)$ \\
& \# Influential Individuals \\
& Raw & Laakso & Golosov \\
\hline Panel A: No Controls & & \\
Fractionalization & $0.74^{* *}$ & $0.47^{*}$ & $0.45^{*}$ \\
& $(0.24)$ & $(0.16)$ & $(0.15)$ \\
& & & \\
Observations & 269 & 269 & 269 \\
R-squared & 0.017 & 0.014 & 0.014 \\
Mean Dep. Var. & 9.137 & 5.900 & 5.157 \\
\hline Panel B: Full Controls & & \\
Fractionalization & $0.80^{*}$ & $0.54^{* *}$ & $0.53^{* *}$ \\
& $(0.26)$ & $(0.16)$ & $(0.14)$ \\
& & & \\
Observations & 269 & 269 & 269 \\
R-squared & 0.053 & 0.066 & 0.069 \\
Mean Dep. Var. & 9.137 & 5.900 & 5.157 \\
\hline
\end{tabular}

Notes: Results from village-level regressions with municipal fixed-effects. The dependent variable is the number of distinct individuals named as influential by survey respondents (Column 1), the effective number of distinct individuals named as influential by survey respondents computed as Laakso (Column 2), the effective number of distinct individuals named as influential by survey respondents computed as Golosov (Column 3). In Panel B regressions control for village population, whether the village is classified as rural, average education, age, household size, and length of residence, as well as the share of population that is female, receives remittances from abroad, and benefits from a CCT program. Standard errors (in parentheses) are clustered by municipality. ${ }^{*} \mathrm{p}<0.05,{ }^{* *} \mathrm{p}<.01$.

Next we provide estimates of regression (1) but using different measures of political competition as outcomes. In Table 7 we first report the correlation between social fractionalization and political competition in barangay elections. In Column 1 we show that a one standard deviation increase in social fractionalization is associated with an increase of 0.07 standard deviations in our index of political competition for barangay elections. In Columns 2-6 we then show the estimates for the individual outcomes that constitute the index ${ }^{22}$ Social fractionalization is positively correlated with the raw and effective number of candidates running for barangay captain (Columns 2-4) and for the barangay council (Column 6). For example, a one standard deviation increase in social fractionalization is associated with roughly an additional candidate in the barangay council

\footnotetext{
${ }^{22} \mathrm{As}$ above, the $p$-values for each of the 5 components of the political competition index are below .01 . Thus, even a very conservative Bonferroni correction would lead us to reject the null of no effects for all the outcomes at the 5 percent level.
} 
Table 7: Network Fractionalization and Competition in Barangay Elections

\begin{tabular}{lcccccc}
\hline \hline & $\begin{array}{c}(1) \\
\text { Index }\end{array}$ & \multicolumn{2}{c}{$\begin{array}{c}\text { \# Candidates Bgy. Cpt. } \\
\text { Raw }\end{array}$} & $\begin{array}{c}\text { Laakso } \\
\text { Golosov }\end{array}$ & $\begin{array}{c}\text { Win } \\
\text { Margin }\end{array}$ & $\begin{array}{c}\text { \# Candidates } \\
\text { Bgy. Councilors }\end{array}$ \\
\hline $\begin{array}{lcccccc}\text { Panel A: No Controls } \\
\text { Fractionalization }\end{array}$ & $0.07^{* *}$ & $0.07^{* *}$ & $0.04^{* *}$ & $0.03^{* *}$ & $-1.73^{* *}$ & $0.72^{* *}$ \\
& $(0.01)$ & $(0.01)$ & $(0.00)$ & $(0.00)$ & $(0.25)$ & $(0.07)$ \\
Observations & & & & & & \\
R-squared & 31,344 & 31,344 & 30,986 & 31,344 & 30,597 & 31,344 \\
Mean Dep. Var. & 0.005 & 0.004 & 0.003 & 0.002 & 0.002 & 0.012 \\
Std. Dev. Dep. Var. & 0.984 & 2.176 & 1.875 & 1.667 & 36.89 & 16.83 \\
\hline Panel B: Full Controls & 0.988 & 0.685 & 0.625 & 36.91 & 7.020 \\
Fractionalization & $0.06^{* *}$ & $0.05^{* *}$ & $0.04^{* *}$ & $0.03^{* *}$ & $-1.82^{* *}$ & $0.61^{* *}$ \\
& $(0.01)$ & $(0.01)$ & $(0.01)$ & $(0.00)$ & $(0.30)$ & $(0.06)$ \\
& & & & & & \\
Observations & 31,306 & 31,306 & 30,948 & 31,306 & 30,559 & 31,306 \\
R-squared & 0.018 & 0.012 & 0.008 & 0.007 & 0.007 & 0.052 \\
Mean Dep. Var. & 0 & 2.176 & 1.875 & 1.667 & 36.89 & 16.83 \\
Std. Dev. Dep. Var. & 0.984 & 0.988 & 0.685 & 0.625 & 36.91 & 7.020 \\
\hline
\end{tabular}

Notes: Results from village*election-level regressions with municipal*election fixed-effects. The dependent variable is an index (Column 1) capturing the competitiveness of barangay elections (number of candidates for barangay captains, win margin and number of candidates for barangay councilors), the number of candidates for barangay captain (Column 2), the effective number of candidates for barangay captain computed as Laakso (Column 3), the effective number of candidates for barangay captain computed as Golosov (Column 4), the win margin in the barangay captain election (Column 5) and the number of candidates for barangay councilor (Column 6). In Panel B regressions control for village-level average age, average length of stay in the village, gender ratio, village population, the number of distinct families in the village, whether the village is classified as rural, as well as education levels in the village, occupation in the village and average per capita income and poverty incidence. Standard errors (in parentheses) are clustered by municipality. ${ }^{*} \mathrm{p}<0.05,{ }^{* *} \mathrm{p}<.01$.

elections. Also, social fractionalization is positively correlated with more competitive races as measured by the win margin between the winner and runner-up in barangay captain elections (Column 5). A one-standard deviation increase in social fractionalization is associated with a decrease in the win margin of almost 2 percentage points, an effect of almost 5 percent relative to the sample mean. The point estimates are remarkably stable to controlling for the same set of village covariates included in the public goods regressions (Panel B, Table 7) or to reduced form or instrumental variables regressions based on the network of individuals older than 45 (Table A.6). In Tables A.5 A.8 we report, for our political competition index, the same set of robustness checks conducted on the public goods estimates. 
Finally, we study how social fractionalization correlates with political competition in mayoral elections. In this case, we keep the number of candidates constant, allowing us to explore whether races in more fragmented villages are more competitive. The estimates reported in Columns 1-2 of Table 8 are consistent with previous findings and suggest that mayoral races are more tightly contested in highly fragmented villages.

Identifying all the potential mediators between social fractionalization and public goods provision in our context is challenging. The evidence presented above suggests that collective action and preference heterogeneity play a limited role in our context. Previous research provides evidence of a positive correlation between electoral competition and public goods provision (Besley and Burgess, 2002; Crost and Kambhampati, 2010; Rosenzweig, 2015), which suggests that political competition may be an important mediator between fractionalization and public goods provision. Indeed, in Table A.9 we show that political competition and public goods provision are positively correlated in our sample. However, political competition may simply be a separate outcome (not a mediator) and there are other channels through which fractionalization may impact the redistributive strategies of politicians. ${ }^{23}$

Our theory suggests that socially fragmented villages receive more public goods at the expense of private or clientelistic transfers to clans. In fact, in the Philippines, Khemani (2015) reports a strong negative correlation between the extent of clientelism (proxied by vote buying) and public goods provision at the local level. Unfortunately we do not have access to systematic measures of vote buying or private transfers across a wide number of villages. However, a very strong correlate of vote-buying or clientelism in the Philippines is turnout. ${ }^{24}$ Consistent with this, in Columns 3-4 of Table 8 we show that a one standard deviation increase in social fractionalization is associated with a 1 percentage point decrease in turnout. While indirect, this evidence is consistent with lower clientelism in highly fragmented villages.

\footnotetext{
${ }^{23}$ For example, Tajima, Samphantharak and Ostwald (2018) argue that segregation can reduce or neutralize the negative effects of diversity on public goods provision. Their effect operates through the possible exclusion of ethnic groups living in different villages in their constituency. In our context, exclusion of clans within villages is unlikely given the small geographical area and population of barangays in our sample.

${ }^{24}$ This is consistent with the theory of turnout buying put forward by Nichter (2008).
} 
Table 8: Network Fractionalization, Turnout and Win Margin in Municipal elections

\begin{tabular}{lcccc}
\hline \hline & $(1)$ & $(2)$ & $(3)$ & $(4)$ \\
& \multicolumn{2}{c}{ Win Margin } & \multicolumn{2}{c}{ Turnout } \\
\hline Fractionalization & $-1.94^{* *}$ & -0.63 & $-0.80^{* *}$ & $-0.68^{* * *}$ \\
& $(0.35)$ & $(0.33)$ & $(0.14)$ & $(0.15)$ \\
& & & & \\
Controls & No & Yes & No & Yes \\
Observations & 17,023 & 17,021 & 18,352 & 18,350 \\
R-squared & 0.006 & 0.021 & 0.004 & 0.016 \\
Mean Dep. Var. & 33.60 & 33.60 & 72.64 & 72.64 \\
\hline
\end{tabular}

Notes: Results from precinct-level regressions with municipal fixed-effects. The dependent variable is win margin in the 2010 municipal elections (Columns 1-2) and turnout in the 2010 municipal elections (Columns 3-4). In Columns 2 and 4, regressions control for village-level average age, average length of stay in the village, gender ratio, village population, the number of distinct families in the village, whether the village is classified as rural, as well as education levels in the village, occupation in the village and average per capita income and poverty incidence. Standard errors (in parentheses) are clustered by municipality. ${ }^{*} \mathrm{p}<0.05,{ }^{* *}$ $\mathrm{p}<.01$.

\section{Conclusion}

We find compelling evidence that network structures-specifically, the fractionalization of social networks-are associated with greater incentives for politicians to provide public goods and with higher levels of electoral competition. Our paper is among the first to provide such evidence using large-scale social networks data. We use a number of approaches to account for potential confounders of social fractionalization and establish robustness of our findings to alternative samples and estimation strategies.

We highlight alternative ways in which social fractionalization may impact local governance depending on the institutional context that shapes the incentives for politicians and citizens to exert effort towards the provision of public goods. While fractionalization may indeed make it difficult for the community to act collectively and/or to aggregate heterogenous preferences, these may be less relevant in contexts where politicians (and not communities) are responsible for the provision of public goods which are funded with transfers (rather than local taxes). In these contexts, we argue that fractionalization may also be associated with lower concentration of political influence, which limits the likelihood of elite capture and makes relatively more appealing for politicians to spend in public goods (rather than in clientelistic transfers) as an electoral strategy. 
Our work highlights the challenges of local public goods provision in decentralized contexts. Previous literature has highlighted the potential for elite capture to undermine the potential benefits of decentralization on local governance (Bardhan, 2002; Ostwald, Tajima and Samphantharak, 2016). Our study shows how social structures can shape the degree of elite capture, electoral competition, and the incentives of politicians to provide public goods. Thus, we contribute to a growing literature showing that the effects of policy interventions depend on the cultural and social context (Rao and Walton, 2004; Ashraf et al., 2016). 


\section{References}

Abinales, Patricio N and Donna J Amoroso. 2017. State and Society in the Philippines. Rowman \& Littlefield.

Acemoglu, Daron, Tristan Reed and James Robinson. 2014. “Chiefs: Economic Development and Elite Control of Civil Society in Sierra Leone." Journal of Political Economy 122(2):319-368.

Alesina, Alberto, Arnaud Devleeschauwer, William Easterly, Sergio Kurlat and Romain Wacziarg. 2003. "Fractionalization." Journal of Economic Growth 8(2):155-194.

Alesina, Alberto, Reza Baqir and William Easterly. 1999. "Public Goods and Ethnic Divisions." The Quarterly Journal of Economics 114(4):1243-1284.

Amorim-Neto, Octavio and Gary W. Cox. 1997. “Electoral Institutions, Cleavage Structures, and the Number of Parties." American Journal of Political Science 41(1):149-174.

Anderson, Michael L. 2008. "Multiple Inference and Gender Differences in the Effects of Early Intervention: A Reevaluation of the Abecedarian, Perry Preschool, and Early Training Projects." Journal of the American Statistical Association 103(484):1481-1495.

Aquino, Clemen C. 2004. "Mula sa Kinaroroonan: Kapwa, Kapatiran and "Bayan in Philippine Social Science." Asian Journal of Social Science 32(1):105-139.

Ashraf, Nava, Natalie Bau, Nathan Nunn and Alessandra Voena. 2016. "Bride price and female education." National Bureau of Economic Research .

Azfar, Omar, Tugrul Gurgur, Satu Kähkönen, Anthony Lanyi and Patrick Meagher. 2000. “Decentralization and governance: An empirical investigation of public service delivery in the Philippines." Washington, DC: University of Maryland Center for Institutional Reform and the Informal Sector and the World Bank.

Bardhan, Pranab. 2002. "Decentralization and Governance in Development." Journal of Economic Perspectives 16(4).

Besley, Timothy and Robin Burgess. 2002. “The Political Economy of Government Responsiveness: Theory and Evidence from India*." The Quarterly Journal of Economics 117(4):1415-1451. 
Calvo, Ernesto and Maria Victoria Murillo. 2009. "Selecting Clients: Partisan Networks and Electoral Benefits of Targeted Distribution.".

Capuno, Joseph. 2012. "The PIPER Forum on 20 Years of Fiscal Decentralization: A Synthesis." Philippine Review of Economics 49(1):191-202.

Chandrasekhar, Arun and Randall Lewis. 2011. "Econometrics of Sampled Networks." mimeo .

Clemente, Jose Antonio, Delia Belleza, Angela Yu, Effie Vinia Catibog, Goyena Solis and Jason Laguerta. 2008. “Revisiting the Kapwa Theory: Applying Alternative Methodologies and Gaining New Insights." Philippine Journal of Psychology 41:1-32.

Corpuz, Onofre D. 1965. The Philippines. Englewood Cliffs, New Jersey: Prentice-Hall.

Covar, Prospero. 1998. Larangan: seminal essays on Philippine culture. National Commission for Culture and the Arts.

Crost, Benjamin and Uma S. Kambhampati. 2010. "Political Market Characteristics and the Provision of Educational Infrastructure in North India." World Development 38(2):195 - 204.

Cruz, Cesi. 2019. "Social Networks and the Targeting of Vote Buying." Comparative Political Studies 52(3):382-411.

Cruz, Cesi, Julien Labonne and Pablo Querubin. 2017. “Politician Family Networks and Electoral Outcomes: Evidence from the Philippines." American Economic Review 107(10):3006-3037.

Dahl, Robert A. 1973. Polyarchy: Participation and Opposition. Yale University Press.

Desmet, Klaus, Ignacio Ortuño-Ortín and Shlomo Weber. 2017. “Peripheral diversity: transfers versus public goods." Social Choice and Welfare 49(3):787-823.

Easterly, William and Ross Levine. 1997. "Africa's Growth Tragedy: Policies and Ethnic Divisions*." The Quarterly Journal of Economics 112(4):1203-1250.

Enriquez, Virgilio G. 1986. “Kapwa: A core concept in Filipino social psychology.” Philippine world view pp. 6-19. 
Eubank, Nicholas, Guy Grossman, Melina Platas and Jonathan Rodden. 2017. "Social Networks, Social Context, and Political Participation: Evidence from Uganda.".

Fafchamps, Marcel and Julien Labonne. 2017. “Do Politicians' Relatives Get Better Jobs? Evidence from Municipal Elections in the Philippines." Journal of Law, Economics E Organization 33(2):268300.

Fearon, James D. 2003. "Ethnic and Cultural Diversity by Country." Journal of Economic Growth $8(2): 195-222$.

Fegan, Brian. 2009. Entrepreneurs in Votes and Violence: Three Generations of a Peasant Political Family. In An Anarchy of Families: State E Family in the Philippines, ed. Alfred McCoy. Madison, WI: University of Wisconsin Press pp. 33-108.

Fernandez, Luisa. 2012. “Design and Implementation Features of the National Household Targeting System in the Philippines." World Bank - Philippines Social Protection Note No 5.

Freeman, Linton C. 1977. "A Set of Measures of Centrality Based on Betweenness." Sociometry 40:35-41.

Gao, Eleanor. 2016. “Tribal Mobilization, Fragmented Groups, and Public Goods Provision in Jordan." Comparative Political Studies 49(10):1372-1403.

Girvan, M. and M. E. J. Newman. 2002. "Community structure in social and biological networks." Proceedings of the National Academy of Sciences 99(12):7821-7826.

Golosov, Grigorii V. 2010. “The Effective Number of Parties: A New Approach." Party Politics 16:171-192.

Haim, Dotan. 2018. "Civilian Social Networks and Credible Counterinsurgency." UCSD, mimeo .

Hollnsteiner, Mary. 1963. The Dynamics of Power in a Philippine Municipality. University of the Philippines.

Huckfeldt, Robert and John Sprague. 1991. “Discussant Effects on Vote Choice: Intimacy, Structure, and Interdependence." The Journal of Politics 53:122-158. 
Huckfeldt, Robert, Paul Allen Beck, Russell J. Dalton and Jeffrey Levine. 1995. "Political Environments, Cohesive Social Groups, and the Communication of Public Opinion." American Journal of Political Science 39(4):1025-1054.

Hughes, D. Alex. 2016. Political Actors Use Social Networks to Coordinate Behavior PhD thesis University of California, San Diego.

Hutchcroft, Paul. 2012. "Re-slicing the pie of patronage: the politics of internal revenue allotment in the Philippines, 1991-2010." Philippine Review of Economics 49(1):109-134.

Hutchcroft, Paul and Joel Rocamora. 2003. "Strong Demands and Weak Institutions: The Origins and Evolution of the Democratic Deficit in the Philippines." Journal of East Asian Studies 3:259-292.

Jackson, Matthew O. 2010. Social and Economic Networks. Princeton University Press Princeton University Press.

Katz, Elihu and Paul F. Lazarsfeld. 1955. Personal Influence, the Part Played by People in the Flow of Mass Communications. New York: Free Press.

Khemani, Stuti. 2015. “Buying votes versus supplying public services: Political incentives to under-invest in pro-poor policies." Journal of Development Economics 117:84-93.

Kitschelt, Herbert and Steven Wilkinson. 2007. Patrons, Clients, and Policies. Cambridge: Cambridge University Press.

Kustov, Alexander and Giuliana Pardelli. 2018. "Ethnoracial Homogeneity and Public Outcomes: The (Non)effects of Diversity." American Political Science Review pp. 1-8.

Laakso, Markku and Rein Taagepera. 1979. "Effective Number of Parties: A Measure with Application to West Europe." Comparative Political Studies 12:3-27.

Lande, Carl H. 1964. Leaders, Factions, and Parties: the Structure of Philippine Politics. New Haven: Yale University Press.

Larson, Jennifer M and Janet I Lewis. 2017. "Ethnic Networks." American Journal of Political Science 61(2):350-364. 
Lizzeri, Alessandro and Nicola Persico. 2004. "Why did the Elites Extend the Suffrage? Democracy and the Scope of Government, with an Application to Britain's 'Age of Reform'." The Quarterly Journal of Economics 119(2):707-765.

Llanto, Gilberto M. 2012. “The Assignment of Functions and Intergovernmental Fiscal Relations in the Philippines 20 Years after Decentralization." Philippine Review of Economics 49(1):37-80.

Lublin, David. 2017. "Electoral Systems, Ethnic Heterogeneity and Party System Fragmentation." British Journal of Political Science 47(2):373-389.

Martinez-Bravo, Monica, Gerard Padro i Miquel, Nancy Qian and Yang Yao. 2012. Social Fragmentation, Public Goods and Elections: Evidence from China. Working Paper 18633 National Bureau of Economic Research.

McCoy, Alfred W. 2009. An anarchy of families: State and family in the Philippines. Univ of Wisconsin Press.

Mendoza, Ronald U., Edsel L. Beja Jr., Victor S. Venida and David B. Yap. 2016. "Political dynasties and poverty: measurement and evidence of linkages in the Philippines." Oxford Development Studies 44(2):189-201.

Mendoza, Ronald U., Jan Cruz and David B. Yap. 2014. “Political Party Switching: It's More Fun in the Philippines." Asian Institute of Management (AIM) Working Paper No. 14-019 .

Miguel, Edward and Mary Kay Gugerty. 2005. “Ethnic diversity, social sanctions, and public goods in Kenya." Journal of Public Economics 89(11):2325 - 2368.

Miralao, Virginia A. 1997. "The Family, Traditional Values and the Sodocultural Transformation of Philippine Society." Philippine Sociological Review 45(1/4):189-215.

Moscona, Jacob, Nathan Nunn and James A. Robinson. 2017. "Keeping It in the Family: Lineage Organization and the Scope of Trust in Sub-Saharan Africa." American Economic Review 107(5):565-71.

Munshi, Kaivan and Mark Rosenzweig. 2018. "Ethnic Diversity and the Under-Supply of Public Goods." NBER Working Paper 19197. 
Nichter, Simeon. 2008. "Vote Buying or Turnout Buying? Machine Politics and the Secret Ballot." American Political Science Review 102(1):19-31.

Ostwald, Kai, Yuhki Tajima and Krislert Samphantharak. 2016. “Indonesia's Decentralization Experiment: Motivations, Successes, and Unintended Consequences." Journal of Southeast Asian Economies 33(2):139-156.

Padgett, John F. and Paul D. McLean. 2006. “Organizational Invention and Elite Transformation: The Birth of the Partnership Systems in Renaissance Florence." American Journal of Sociology 111(5):1463-1568.

Pons, Pascal and Matthieu Latapy. 2005. Computing Communities in Large Networks Using Random Walks. In Computer and Information Sciences - ISCIS 2005, ed. pInar Yolum, Tunga Güngör, Fikret Gürgen and Can Özturan. Berlin, Heidelberg: Springer Berlin Heidelberg pp. 284-293.

Potter, Joshua D. 2014. "Demographic Diversity and District-Level Party Systems." Comparative Political Studies 47(13):1801-1829.

Rao, Vijayendra and Michael Walton. 2004. Culture and Public Action: A Cross-Disciplinary Dialogue on Development Policy. Stanford University Press.

Reyes, Jeremiah. 2015. "Loób and Kapwa: An Introduction to a Filipino Virtue Ethics." Asian Philosophy 25(2):148-171.

Rogers, Steven. 2004. "Philippine Politics and the Rule of Law." Journal of Democracy 15(4):116.

Rosenzweig, Steven C. 2015. "Does electoral competition affect public goods provision in dominantparty regimes? Evidence from Tanzania." Electoral Studies 39:72 - 84.

Rubin, Michael. 2018. "Rebel Territorial Control and Civilian Collective Action in Civil War. Evidence from the Philippines." UCSAE, mimeo .

Sidel, John T. 1999. Capital, Coercion, and Crime: Bossism in the Philippines. Contemporary issues in Asia and the Pacific Stanford University Press.

Soifer, Hillel David. 2016. "Regionalism, Ethnic Diversity, and Variation in Public Good Provision by National States." Comparative Political Studies 49(10):1341-1371. 
Tajima, Yuhki, Krislert Samphantharak and Kai Ostwald. 2018. “Ethnic Segregation and Public Goods: Evidence from Indonesia." American Political Science Review 112(3):637-653.

Timberman, David G. 1991. A Changeless Land: Continuity and Change in Philippine Politics. M.E. Sharpe.

Todd, Emmanuel. 1985. The Explanation of Ideology: Family Structures and Social Systems. B. Blackwell.

Troland, Erin. 2016. “Do Fiscal Transfers Increase Local Revenue Collection? Evidence From The Philippines". Working Paper. Available at SSRN: https://ssrn. com/abstract=3242240.

Wimmer, Andreas. 2016. “Is Diversity Detrimental? Ethnic Fractionalization, Public Goods Provision, and the Historical Legacies of Stateness." Comparative Political Studies 49(11):1407-1445.

Xu, Yiqing and Yang Yao. 2015. "Informal Institutions, Collective Action, and Public Investment in Rural China." American Political Science Review 109(2):371-391. 


\section{Social Network Structures and the Politics of Public Goods Provision: Evidence from the Philippines}

\section{Online Appendix}

\section{A.1 Variables Definition}

\section{A.1.1 Network Measures}

\section{Edge Betweenness Centrality}

Edge betweenness centrality is the extent to which an edge (marriage between 2 families) serves as a link between different groups of families. It assesses centrality by looking at whether the edge is an important hub in the paths traversing the network and is calculated using the number of shortest paths in the network that necessarily pass through the edge. This measure is analogous to betweenness centrality, which considers the relative importance of a node in the paths traversing the network (Freeman, 1977).

In the family network $f$, let $P_{e}(k j)$ indicate the number of shortest paths between family $k$ and family $j$ that necessarily pass through edge $e$, while $P(k j)$ is the total number of shortest paths between $k$ and $j$.

The ratio $P_{e}(k j) / P(k j)$ approximates the importance of edge $e$ in connecting $k$ and $j$. If $P_{e}(k j)=$ $P(k j)$, yielding a ratio of 1 , then edge $e$ lies on all of the shortest paths connecting families $k$ and $j$. Conversely, if $P_{e}(k j)=0$, then the intermarriage represented by edge $e$ is not important for connecting families $k$ and $j$.

Edge betweenness centrality is calculated by averaging this ratio for the entire network.

$$
\text { Betweenness }_{e}(f)=\sum \frac{P_{e}(k j)}{P(k j)}
$$




\section{A.1.2 Effective Number of Candidates Indices}

The Laakso and Taagepera (1979) index is given by $N=1 / \sum_{i=1}^{n} s_{i}^{2}$, where $n$ is the number of candidates and $s_{i}$ is the share of votes of candidate $i$.

The index by Golosov (2010) is defined as $N=\sum_{i=1}^{n} s_{i} /\left(s_{i}+s_{1}^{2}-s_{i}^{2}\right)$, where $s_{1}$ is the vote share of the candidate with the largest number of votes.

\section{A.1.3 Computing Indices, following Anderson (2008)}

Here we explain how we compute our public goods and political competition indices. The public goods index aggregates dummies for whether the barangay has an elementary school, a high school, a public market, a health center or a community water system. The political competition index aggregates the win margin (vote share of the candidate that received the most votes in that precinct minus vote share of the runner-up in that precinct) and the number of candidates running in the race. We also use the indices of effective number of candidates, proposed by Laakso and Taagepera (1979) and Golosov (2010).

As carefully explained by Anderson (2008), we compute the public goods index and the electoral competition indices as follows:

1. For all outcomes $\left(y_{i k}\right)$ in each of the two categories, switch signs where necessary so that the positive direction always indicates a better outcome.

2. Compute $z_{i k}=\frac{y_{i k}-\overline{y_{k}}}{\sigma_{k}^{y}}$, where $\overline{y_{k}}$ is the sample average and $\sigma_{k}^{y}$ the standard deviation of $y_{i k}$.

3. Compute $s_{i}=\left(\mathbf{1}^{\prime} \hat{\Sigma}^{-1} \mathbf{1}\right)^{-1}\left(\mathbf{1}^{\prime} \hat{\Sigma}^{-\mathbf{1}} \mathbf{z}_{\mathbf{i}}\right)$, where $\mathbf{1}$ is a column vector of $1^{\prime}$ s. $\hat{\boldsymbol{\Sigma}}^{-\mathbf{1}}$ is the inverted covariance matrix, and $\mathbf{z}_{\mathbf{i}}$ is vector of all outcomes for individual $i$. 


\section{A.2 Descriptive Statistics}

Table A.1: Describing our Sample

\begin{tabular}{lcc}
\hline \hline & $(1)$ & $(2)$ \\
& Sample & National Average \\
\hline Population & $1,412.28$ & $2,196.38$ \\
& $(1535.37)$ & $(4629.95)$ \\
Urban & 0.11 & 0.24 \\
& $(0.31)$ & $(0.43)$ \\
Religious diversity & 0.20 & 0.21 \\
& $(0.22)$ & $(0.20)$ \\
Ethnic diversity & 0.18 & 0.21 \\
& $(0.23)$ & $(0.24)$ \\
Elementary school & 0.81 & 0.77 \\
& $(0.40)$ & $(0.42)$ \\
High school & 0.21 & 0.23 \\
Market & $(0.41)$ & $(0.42)$ \\
Health centre & 0.19 & 0.18 \\
& $(0.39)$ & $(0.38)$ \\
Waterworks & 0.64 & 0.68 \\
& $(0.48)$ & $(0.47)$ \\
& 0.60 & 0.62 \\
& $(0.49)$ & $(0.49)$ \\
\hline
\end{tabular}

Source: 2010 Census. Column 1 reports the mean and standard deviation (in parenthesis) of the relevant variables for villages in our sample. Column 2 reports the mean and standard deviation (in parenthesis) of the relevant variables for villages in the country. 
Table A.2: Descriptive Statistics

\begin{tabular}{lccccc}
\hline & Mean & Std. Dev. & Median & Min & Max \\
\hline Number of communities & 45.89 & $(41.04)$ & 34.00 & 1.00 & 614.00 \\
Share largest community & 0.13 & $(0.06)$ & 0.12 & 0.02 & 1.00 \\
Share 2nd largest community & 0.10 & $(0.04)$ & 0.10 & 0.02 & 0.50 \\
Fractionalization (edge) & 0.00 & $(1.00)$ & 0.20 & -21.98 & 1.46 \\
Fractionalization (walktrap) & 0.00 & $(1.00)$ & 0.23 & -14.69 & 1.30 \\
Fractionalization (edge) 1st population tercile & -0.60 & $(1.25)$ & -0.35 & -21.98 & 1.30 \\
Fractionalization (edge) 2nd population tercile & 0.09 & $(0.62)$ & 0.19 & -6.54 & 1.34 \\
Fractionalization (edge) 3rd population tercile & 0.51 & $(0.66)$ & 0.60 & -21.98 & 1.46 \\
Elementary School & 0.81 & $(0.40)$ & 1.00 & 0.00 & 1.00 \\
High School & 0.21 & $(0.41)$ & 0.00 & 0.00 & 1.00 \\
Market & 0.19 & $(0.39)$ & 0.00 & 0.00 & 1.00 \\
Health centre & 0.64 & $(0.48)$ & 1.00 & 0.00 & 1.00 \\
Waterworks & 0.60 & $(0.49)$ & 1.00 & 0.00 & 1.00 \\
Number of candidates barangay captain & 2.17 & $(0.99)$ & 2.00 & 1.00 & 21.00 \\
Effective no. of candidates barangay captain (Laakso) & 1.87 & $(0.69)$ & 1.95 & 1.00 & 8.17 \\
Effective no. of candidates barangay captain (Golosov) & 1.67 & $(0.62)$ & 1.70 & 0.00 & 7.36 \\
Win margin (barangay captain elections) & 36.96 & $(36.94)$ & 19.85 & 0.07 & 100 \\
Number of candidates barangay council & 16.82 & $(7.01)$ & 15.00 & 0.00 & 96.00 \\
\hline
\end{tabular}

\section{A.3 Additional Results}

Table A.3: Fractionalization and Public Goods: Robustness to Excluding Outliers

\begin{tabular}{|c|c|c|c|c|}
\hline & (1) & (2) & (3) & (4) \\
\hline & \multicolumn{2}{|c|}{ Fractionalization: } & \multicolumn{2}{|c|}{ Population: } \\
\hline & $1 \%$ & $5 \%$ & $1 \%$ & $5 \%$ \\
\hline \multirow[t]{2}{*}{ Fractionalization } & $0.07^{* *}$ & $0.06^{* *}$ & $0.03^{* *}$ & $0.02^{* *}$ \\
\hline & $(0.01)$ & $(0.01)$ & $(0.01)$ & $(0.01)$ \\
\hline Observations & 15,147 & 13,908 & 15,133 & 13,888 \\
\hline R-squared & 0.182 & 0.175 & 0.191 & 0.171 \\
\hline
\end{tabular}

Notes: Results from village-level regressions with municipal fixed-effects. The dependent variable is an index capturing the availability of key public goods at the village-level (elementary schools, high schools, markets, health centre and water systems). In Column 1, we remove all villages in the top and bottom 1\% of the distribution of fractionalization. In Column 2, we remove all villages in the top and bottom $5 \%$ of the distribution of fractionalization. In Column 3, we remove all villages in the top and bottom $1 \%$ of the distribution of population. In Column 4, we remove all villages in the top and bottom $5 \%$ of the distribution of population. Regressions control for village-level average age, average length of stay in the village, gender ratio, village population, the number of distinct families in the village, whether the village is classified as rural, as well as education levels in the village, occupation in the village and average per capita income and poverty incidence. Standard errors (in parentheses) are clustered by municipality. ${ }^{*} \mathrm{p}<0.05,{ }^{* *} \mathrm{p}<.01$. 
Table A.4: Fractionalization and Public Goods: Robustness to Alternative Samples and Controls

\begin{tabular}{|c|c|c|c|c|c|c|}
\hline & (1) & (2) & (3) & (4) & (5) & (6) \\
\hline & & Exclude: & & \multicolumn{3}{|c|}{ Control for: } \\
\hline & Urban & "Hometown" & ARMM & $\begin{array}{l}\text { Incumbent } \\
\text { Family }\end{array}$ & $\begin{array}{l}\text { Incu. \& Chall. } \\
\text { Family }\end{array}$ & $\begin{array}{l}\text { Ethnic \& Relig. } \\
\text { Fractionalization }\end{array}$ \\
\hline Fractionalization & $\begin{array}{l}0.05^{* *} \\
(0.01)\end{array}$ & $\begin{array}{l}0.05^{* *} \\
(0.01)\end{array}$ & $\begin{array}{l}0.07^{* *} \\
(0.01)\end{array}$ & $\begin{array}{l}0.06^{* *} \\
(0.01)\end{array}$ & $\begin{array}{l}0.05^{* *} \\
(0.01)\end{array}$ & $\begin{array}{l}0.05^{* *} \\
(0.01)\end{array}$ \\
\hline Observations & 13,740 & 10,921 & 13,147 & 9,704 & 8,746 & 15,445 \\
\hline R-squared & 0.141 & 0.157 & 0.174 & 0.186 & 0.193 & 0.173 \\
\hline
\end{tabular}

Notes: Results from village-level regressions with municipal fixed-effects. The dependent variable is an index capturing the availability of key public goods at the village-level (elementary schools, high schools, markets, health centre and water systems). In Column 1, we drop all villages classified as urban. In Column 2 , we drop villages where the incumbent has the most number of relatives. In Column 3, we drop all villages in ARMM from our sample. In Column 4, we further control for characteristics of the incumbent's family. In Column 5, we further control for characteristics of both the challenger and the incumbent's family. In Column 6, we further control for ethnic and religious fractionalization. Regressions control for village-level average age, average length of stay in the village, gender ratio, village population, the number of distinct families in the village, whether the village is classified as rural, as well as education levels in the village, occupation in the village and average per capita income and poverty incidence. Standard errors (in parentheses) are clustered by municipality. ${ }^{*} \mathrm{p}<0.05,{ }^{* *} \mathrm{p}<.01$ 
Table A.5: Ethnic and Religious Fragmentation, Public Goods and Elections

\begin{tabular}{lcccccc}
\hline \hline & $(1)$ & $(2)$ & $(3)$ & $(4)$ & $(5)$ & $(6)$ \\
& & Public Goods & \multicolumn{2}{c}{ Electoral Competition } \\
\hline Fractionalization*Below & $0.05^{* *}$ & $0.04^{* *}$ & & $0.06^{* *}$ & $0.06^{* *}$ & \\
& $(0.01)$ & $(0.01)$ & & $(0.01)$ & $(0.01)$ & \\
Fractionalization*Above & $0.05^{* *}$ & $0.07^{* *}$ & & $0.05^{* *}$ & $0.06^{* *}$ & \\
& $(0.02)$ & $(0.01)$ & & $(0.01)$ & $(0.01)$ & \\
Fractionalization & & & $0.05^{* *}$ & & & 0.01 \\
& & & $(0.01)$ & & & $(0.02)$ \\
Sample & & & & & & \\
Interaction with: & Full & Full & ARMM & Full & Full & ARMM \\
& Ethnic & Religious & & Ethnic & Religious & \\
Observations & & & & & & \\
R-squared & 15,445 & 15,445 & 2,298 & 31,306 & 31,306 & 4,039 \\
& 0.170 & 0.170 & 0.217 & 0.018 & 0.018 & 0.019 \\
\hline
\end{tabular}

Notes: Results from village-level regressions with municipal*election fixed-effects. In Columns 1 and 4 we interact the fractionalization variable with dummies capturing whether a village is below or above the median in the distribution of ethnic fractionalization. In Columns 2 and 5 we interact the fractionalization variable with dummies capturing whether a village is below or above the median in the distribution of religious fractionalization. In Columns 1-3, the dependent variable is an index capturing the availability of key public goods at the village-level (elementary schools, high schools, markets, health centre and water systems). In Columns 4-6, the dependent variable is an index capturing the competitiveness of barangay elections (number of candidates for barangay captains, win margin and number of candidates for barangay councilors). Regressions control for village-level average age, average length of stay in the village, gender ratio, village population, the number of distinct families in the village, whether the village is classified as rural, as well as education levels in the village, occupation in the village and average per capita income and poverty incidence. Standard errors (in parentheses) are clustered by municipality. ${ }^{*} \mathrm{p}<0.05,{ }^{* *} \mathrm{p}<.01$. 
Table A.6: Fractionalization and Political Competition: Robustness to Alternative Fractionalization Measures

\begin{tabular}{lccccc}
\hline \hline & $(1)$ & $(2)$ & $(3)$ & $(4)$ & $(5)$ \\
& \multicolumn{2}{c}{ Over 45 } & \multicolumn{2}{c}{ Communities Weighted by: } & Walktrap \\
& OLS & IV & Family Size & \# Voters & Algorithm \\
\hline Fractionalization & $0.07^{* *}$ & $0.12^{* *}$ & $0.05^{* *}$ & $0.05^{* *}$ & $0.05^{* *}$ \\
& $(0.01)$ & $(0.01)$ & $(0.01)$ & $(0.01)$ & $(0.01)$ \\
& & & & & \\
Observations & 31,298 & 31,298 & 31,306 & 31,306 & 31,306 \\
R-squared & 0.019 & & 0.017 & 0.017 & 0.017 \\
\hline
\end{tabular}

Notes: Results from village*election-level regressions with municipal*election fixed-effects (OLS in Columns 1, 3-5 and 2SLS in Column 2). The dependent variable is an index capturing the competitiveness of barangay elections (number of candidates for barangay captains, win margin and number of candidates for barangay councilors). In Column 1 the fractionalization measure is computed using communities obtained on the network restricted to individuals over the age of 45 . In Column 3, the fractionalization measure weights each community by total population in the family. In Column 4 , the fractionalization measure weights each community by the number of members above the age of 18 in the family. In Column 5 , the fractionalization measure is computed using communities obtained with the walktrap algorithm. Regressions control for village-level average age, average length of stay in the village, gender ratio, village population, the number of distinct families in the village, whether the village is classified as rural, as well as education levels in the village, occupation in the village and average per capita income and poverty incidence. Standard errors (in parentheses) are clustered by municipality. ${ }^{*} \mathrm{p}<0.05,{ }^{* *} \mathrm{p}<.01$.

Table A.7: Fractionalization and Political Competition: Robustness to Excluding Outliers

\begin{tabular}{|c|c|c|c|c|}
\hline & (1) & (2) & (3) & (4) \\
\hline & \multicolumn{2}{|c|}{ Fractionalization: } & \multicolumn{2}{|c|}{ Population: } \\
\hline & $1 \%$ & $5 \%$ & $1 \%$ & $5 \%$ \\
\hline \multirow[t]{2}{*}{ Fractionalization } & $0.08^{* *}$ & $0.09^{* *}$ & $0.05^{* *}$ & $0.03^{* *}$ \\
\hline & $(0.01)$ & $(0.01)$ & $(0.01)$ & $(0.01)$ \\
\hline Observations & 30,690 & 28,191 & 30,676 & 28,170 \\
\hline R-squared & 0.019 & 0.022 & 0.019 & 0.019 \\
\hline
\end{tabular}

Notes: Results from village*election-level regressions with municipal*election fixed-effects. The dependent variable is an index capturing the competitiveness of barangay elections (number of candidates for barangay captains, win margin and number of candidates for barangay councilors). In Column 1, we remove all villages in the top and bottom $1 \%$ of the distribution of fractionalization. In Column 2, we remove all villages in the top and bottom $5 \%$ of the distribution of fractionalization. In Column 3, we remove all villages in the top and bottom $1 \%$ of the distribution of population. In Column 4 , we remove all villages in the top and bottom $5 \%$ of the distribution of population. Regressions control for village-level average age, average length of stay in the village, gender ratio, village population, the number of distinct families in the village, whether the village is classified as rural, as well as education levels in the village, occupation in the village and average per capita income and poverty incidence. Standard errors (in parentheses) are clustered by municipality. ${ }^{*} \mathrm{p}<0.05,{ }^{* *} \mathrm{p}<.01$. 
Table A.8: Fractionalization and Political Competition: Robustness to Alternative Samples and Controls

\begin{tabular}{|c|c|c|c|c|c|c|}
\hline & (1) & (2) & (3) & (4) & (5) & (6) \\
\hline & & Exclude: & & \multicolumn{3}{|c|}{ Control for: } \\
\hline & Urban & "Hometown" & ARMM & $\begin{array}{l}\text { Incumbent } \\
\text { Family }\end{array}$ & $\begin{array}{l}\text { Incu. \& Chall. } \\
\text { Family }\end{array}$ & $\begin{array}{l}\text { Ethnic \& Relig. } \\
\text { Fractionalization }\end{array}$ \\
\hline Fractionalization & $\begin{array}{l}0.05^{* *} \\
(0.01)\end{array}$ & $\begin{array}{l}0.05^{* *} \\
(0.01)\end{array}$ & $\begin{array}{l}0.07^{* *} \\
(0.01)\end{array}$ & $\begin{array}{l}0.05^{* *} \\
(0.01)\end{array}$ & $\begin{array}{l}0.05^{* *} \\
(0.01)\end{array}$ & $\begin{array}{l}0.06^{* *} \\
(0.01)\end{array}$ \\
\hline Observations & 27,249 & 21,704 & 27,267 & 19,703 & 17,777 & 31,306 \\
\hline R-squared & 0.024 & 0.021 & 0.023 & 0.021 & 0.027 & 0.018 \\
\hline
\end{tabular}

Notes: Results from village-level regressions with municipal fixed-effects. The dependent variable is an index capturing the competitiveness of barangay elections (number of candidates for barangay captains, win margin and number of candidates for barangay councilors). In Column 1, we drop all villages classified as urban. In Column 2, we drop villages where the incumbent has the most number of relatives. In Column 3, we drop all villages in ARMM from our sample. In Column 4, we further control for characteristics of the incumbent's family. In Column 5, we further control for characteristics of both the challenger and the incumbent's family. In Column 6, we further control for ethnic and religious fractionalization. Regressions control for village-level average age, average length of stay in the village, gender ratio, village population, the number of distinct families in the village, whether the village is classified as rural, as well as education levels in the village, occupation in the village and average per capita income and poverty incidence. Standard errors (in parentheses) are clustered by municipality. ${ }^{*} \mathrm{p}<0.05,{ }^{* *} \mathrm{p}<.01$

Table A.9: Electoral Competition and Public Goods Provision

\begin{tabular}{lccccc}
\hline \hline & $(1)$ & $(2)$ & $(3)$ & $(4)$ & $(5)$ \\
\hline Electoral Competition & $0.03^{* *}$ & $0.01^{* *}$ & $0.01^{* *}$ & $0.01^{*}$ & $0.01^{*}$ \\
& $(0.00)$ & $(0.00)$ & $(0.00)$ & $(0.00)$ & $(0.00)$ \\
Observations & & & & & \\
R-squared & 31,344 & 31,306 & 31,306 & 31,306 & 31,306 \\
\hline
\end{tabular}

Notes: Results from village*election-level regressions with municipal*election fixed-effects. The dependent variable is an index capturing the availability of key public goods at the village-level (elementary schools, high schools, markets, health centre and water systems). The main independent variable is an index capturing the competitiveness of barangay elections (number of candidates for barangay captains, win margin and number of candidates for barangay councilors). In Columns 2-5, we control for village-level average age, average length of stay in the village, gender ratio, village population, the number of distinct families in the village, whether the village is classified as rural. In Columns 3-5, regressions also control for education levels in the village. In Column 4-5, regressions also control for occupation in the village. In Column 5, regressions also control for average per capita income and poverty incidence. Standard errors (in parentheses) are clustered by municipality. ${ }^{*} \mathrm{p}<0.05,{ }^{* *} \mathrm{p}<.01$. 